\title{
Ultrasonic Technique for Production of Nanoemulsions for Food Packaging Purposes: A Review Study
}

\author{
Hamed Ahari * (D) and Mina Nasiri (iD \\ Department of Food Science and Technology, Science and Research Branch, Islamic Azad University, \\ Tehran 1477893855, Iran; nasirimina5879@gmail.com \\ * Correspondence: dr.h.ahari@gmail.com
}

check for updates

Citation: Ahari, H.; Nasiri, M.

Ultrasonic Technique for Production of Nanoemulsions for Food

Packaging Purposes: A Review Study. Coatings 2021, 11, 847. https:// doi.org/10.3390/coatings11070847

Academic Editors: JunSang Ham and Kuk-Hwan Seol

Received: 2 June 2021

Accepted: 30 June 2021

Published: 14 July 2021

Publisher's Note: MDPI stays neutral with regard to jurisdictional claims in published maps and institutional affiliations.

Copyright: (c) 2021 by the authors. Licensee MDPI, Basel, Switzerland. This article is an open access article distributed under the terms and conditions of the Creative Commons Attribution (CC BY) license (https:// creativecommons.org/licenses/by/ $4.0 /)$.

\begin{abstract}
According to the loss of food due to expired shelf life, there is a global concern on food safety among food science researchers, and food microbiologists. So, any approaches contributing to improved food packaging is most welcome. It has been demonstrated that administration of essential oils, fades away the unsolved obstacles of conventional food packaging, reducing environmental concerns compared with conventional food packaging. Along with substantial progresses in nanoscience, there is a great interest toward usage of nanoemulsions-based delivery systems. They have potentials to simplify targeted delivery of compounds in a high surfaced area, aimed at increasing stability, biodegradability, anti-oxidation, and anti-microbial properties. There are a wide range of methods for fabrication of nanoemulsions. Among them, ultrasonic-based approaches have gained an acceptable efficiency for industrial fabrication of essential oils-based nanoemulsions due to refraining from loss of nutrients through non-thermal approaches. In summary, essential-oils based nanoemulsions are significant due to ability for reduction in microbial load of food-borne pathogens, and prolonged shelf life.
\end{abstract}

Keywords: essential oil; food packaging; food safety; nanoemulsion; shelf life; ultrasonication

\section{Introduction}

According to the statistics reported by Food and Agriculture Organization (FAO), it has been calculated that one third of produced food is going to be wasted due to expiring in the shelves of food stores. Food spoilage is accelerated by several enzymatic reactions, microbial activities, and activation of oxygen-driving processes, imposing a financial burden on economy, and recycling industries [1-3]. This problematic challenge is of high importance for establishment of any technological approaches aimed at improvement in food quality. This point accentuates long-lasting shelf life of perishable food products, protecting food from any chemical, physical, environmental, and microbial risks during harvesting, processing, slaughtering, and packaging steps [3-6].

Along with substantial progresses in biotechnology in a wide range of industries like cosmetic, agriculture, and pharmaceutical fields, food science researchers have focused on the development of more efficacious approaches like nanotechnology based ones in food industries, especially in Food Packaging (FP) [7]. In FP, technologies make a barrier between content of the food and exterior atmosphere, and provide assurance for prevention of possible post-contamination of food by food-borne pathogens. Additionally, they elongate the decline phase in growth patterns of microorganisms, and promote food marketing through a prolific advertisement and standardizing [1,6,8-13]. In total, these technologies make an increase in food preservation through refraining from spoilage or food contamination [14]. In addition to aforementioned features, it is of high practical prominence to use material with high sustainability or biodegradability properties in FP, as well as intrinsic anti-microbial effects. Usage of those material can also reduce ecological challenges or environmental concerns with environmentalists, and ecologists $[1,14]$. 
On the other hand, it seems that food science researchers should pay attention to the food marketing, and commit the regulations related to principles of customer orientation by improved appearance of the packaged foods. To be more precise, there are a barrage of desires and preference aroused by consumers for ready-to-eat or mild processed food with maintained quality, re-closable opening or cap, and extended shelf life. They highlight the necessity of more efficient and innovative methods in active FP according to customer desires with reduced environmental challenges $[11,15,16]$.

However, there is a globally imposed environmental concerns on excessive usage of traditional packaging with non-biodegradable material (including: glass, aluminum, foil and laminate, tin sheet or non-tin steel, paper, cardboard, and petroleum derivate plastic) $[3,5,6,10]$. This ideology in FP is traced back to 18th century. Nowadays is the revolutionary era for optimistic views on novel technologies as active packaging $[17,18]$. It seems that chemically formulated food additives, are considered as one of the most efficient approaches in chemoactive FP. Hence, they reduce environmental or socioeconomical side effects, dramatically decrease annual medical costs, and significantly decrease migration of particles from packaging to food content $[5,6,19]$. They have potential in reduction of industrial processing and microbial load, and usage of corrosive chemical disinfectants over raw material in the shelves $[3,5,11,17]$. It has been interrogated that chemoactive FP by natural additives, helps maintenance of color, flavor, putrefaction, moisture content, weight, bioavailability, loaded microorganisms (especially Listeria monocytogenes, Staphylococcus aureus, Shigella dysenteriae, Escherichia coli, Salmonella spp., Campylobacter, Aspergillus flavus, yeasts (Yarrowia lipolytica), and molds) [20-24], oxidation, nutrients, organoleptic properties, and texture. Additionally, chemoactive FP by natural additives can protect food from light, and dust $[1,15,16]$.

Needless to say, chemoactive FP can be beneficial for diminution in the usage of chemical synthetic sensitizers, being extensively used for fresh food (vegetables, pastries, fruit, juice, and fish). In fish industry, there is a growing demand for chilled storage of fish aimed at maintenance of original flavor, texture, and freshness of fish [4,16,25-27]. Benefits of chemoactive FP are observed during production, transportation, processing, storage, and food marketing stages.

Accordingly, there is a wide range of in-depth studies conducted on the development of the most novel approaches in active FP. In total, in this review study, authors firstly tried to address the major concepts of bioactive FP, and utilization of nanoemulsions (NEs) in FP. Then, they specifically focused on the fabrication, and formulation of NEs in FP with critical analysis on the latest experimental studies, especially on research trends investigating ultrasonic-based approaches for NEs fabrication. We believe that such studies aimed at intervening on understanding the mechanisms of entrance, effects of fabrication/formulation types, and anti-microbial/anti-oxidant properties of NEs, will pave the path for the development of more efficient technologies in FP with all of the aforesaid advantages.

\section{Search Method}

Data of this review study were collected through an online literature review (in English language) in Scopus, PubMed, Science Direct databases, and Google Scholar databases and search engine by 8 keywords (including five main keywords: (Essential Oil, AND Food Packaging, AND Food Safety, AND Nanoemulsion, AND Ultrasonication), and three complementary keywords (Anti-bacterial, Anti-oxidant, Shelf life)) commencing from January 2011 until June 2021 time intervals.

\section{Results and Discussion}

\subsection{Role of Essential Oils in Food Packaging}

Nowadays, trends in FP have been gradually have led toward "smart" and more responsive technologies in FP, due to many remained untackled obstacles in chemoactive FP or other eco-friendly FP alternatives [28-30]. 
Industrial usage of bioactive FP have revealed a wide array of advantages according to the type of food due to anti-microbial agents, anti-oxidant agents, anti-viral agents, used as: absorbers or scavengers (or sachets), emitters (for Sulphur dioxide, and flavoring), and self-cooling or self-heating cans containing food [2,5,31,32].

Accordingly, there are accumulatively conducted researches on natural sanitizing agents [5], making a revolutionary era in the usage of Essential Oils (EOs) in FP [33,34], getting rid of unsustainability in recycling processes of the food, reducing environmental concerns on huge mass of chemical wastes [35], improving anti-oxidant features [36], decreasing severity of food-borne outbreaks [36], and decreasing detrimental effects on the human endocrine system [15].

Being literally defined as oily hydrophobic liquids comprised of unsaturated oxygenated hydrocarbons, EOs are considered as a secondary biological metabolite. Those liquid EOs are colorless material at room temperature, and chiefly extracted from aromatic herbal compounds [5].

It has been widely interrogated that these oily compounds have potentials to indicate insecticide or anti-microbial properties [37]. Interestingly, aldehydes, terpenes, and phenols are mainly responsible for effective botanical insecticides. EOs, majorly are able to increase the lag phase of bacteria, inhibit proliferation of microorganisms, induce anti-quorum sensing effects or anti-biofilm features [38], anti-cancer features (through anti-mutagenic or anti-proliferation on cancerous cells) [39], and anti-oxidant effects on food in concentrations more than needed in media cultures [40] (Figure 1). EOs are made of non-volatile/volatile, generally lipophilic, scarcely water-soluble compounds, and being divided into terpenes and hydrocarbons [41].

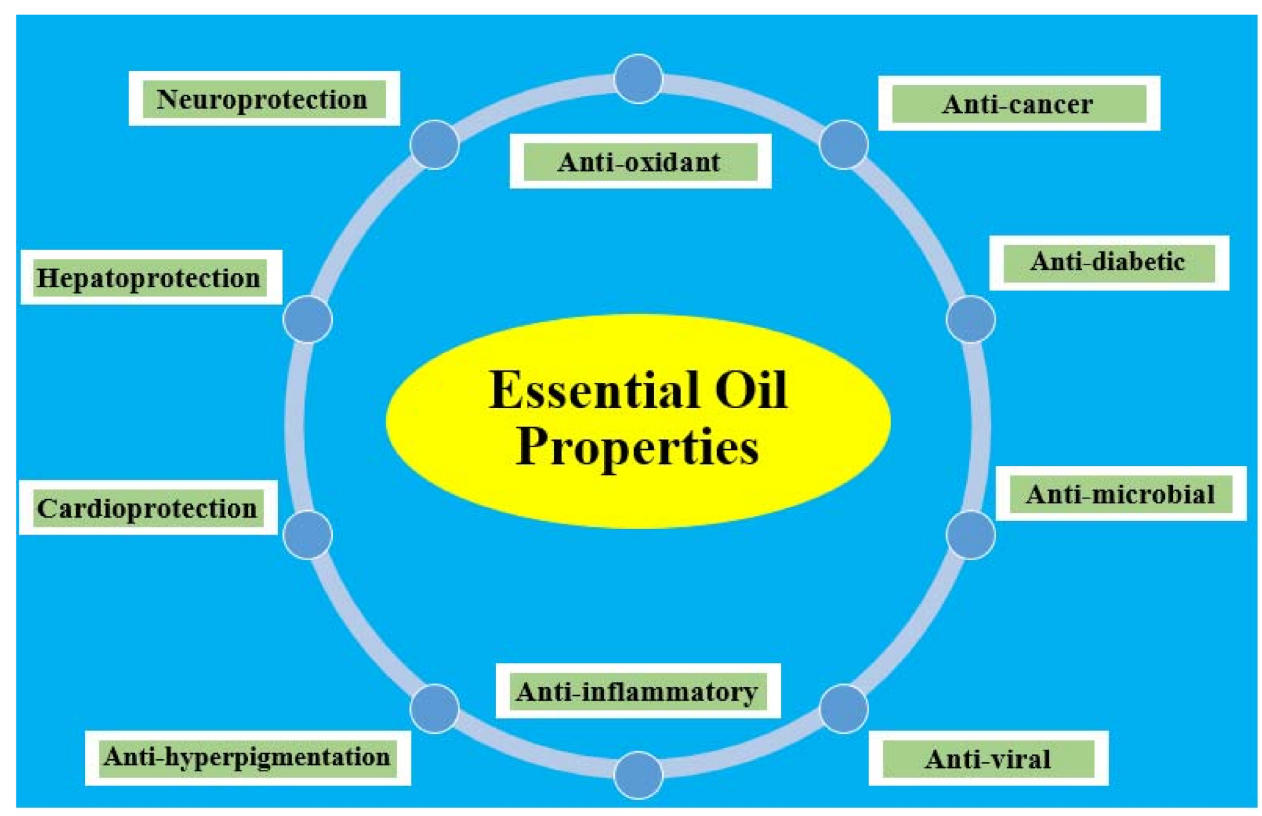

Figure 1. Useful properties of EOs in different fields of science.

These herbal mixtures can be extracted from bark, seed, peel, fruit, root, flowers, and woods of a wide array of plant species. Thyme, cinnamon, garlic, geranium, black pepper, olive, ginger, peppermint, mustard, lemon, seaweed, clove, tea tree, rosemary, salvia, sour lemon peel, oregano, hazelnut, and lavender based oils have been considered as the most efficient types of EOs applied in FP (Table 1) [4,13,23,24]. Figure 2 typically indicates a schematic presentation of chemical structures in EOs. 
Table 1. A short description of some prepared nanoemulsions using EOs.

\begin{tabular}{|c|c|c|c|c|c|c|c|}
\hline Essential Oil & Technique & Emulsifier & Functions & Microorganism & Droplet Size (nm) & $\begin{array}{l}\mathrm{MIC} / \mathrm{MBC} / \mathrm{IZ} \\
(\mathrm{ppm} / \mathrm{ppm} / \mathrm{mm})\end{array}$ & $\begin{array}{c}\text { Year } \\
\text { [Ref.] }\end{array}$ \\
\hline Carvacrol & $\begin{array}{l}\text { Spontaneous } \\
\text { Emulsification }\end{array}$ & Tween 20, 40, 60, 80, and 85 & $\begin{array}{l}\text { Effect of interfacial } \\
\text { composition }\end{array}$ & $\begin{array}{c}\text { Zygosaccharomyces bailii, Saccharomyces } \\
\text { cerevisiae, Brettanomyces bruxellensis, and } \\
\text { Brettanomyces naardenensis }\end{array}$ & from $>5000$ to $<25 \mathrm{~nm}$ & $625 /-/-$ & $\begin{array}{l}2013 \\
{[42]}\end{array}$ \\
\hline Eugenol & Ultrasonic & Tween 80-Tween 20 & Anti-microbial activity & Staphylococcus aureus & 13 & - & $\begin{array}{c}2014 \\
{[43]}\end{array}$ \\
\hline Curcumin & Ultrasonic & $\begin{array}{l}\text { Biopolymer emulsifiers } \\
\text { (lactoferrin and } \\
\text { lactoferrin/alginate } \\
\text { multilayer structure) }\end{array}$ & $\begin{array}{l}\text { Effect of interfacial } \\
\text { composition }\end{array}$ & - & 149 & - & $\begin{array}{l}2015 \\
{[44]}\end{array}$ \\
\hline Cinnamon & Homogenizer & $3 \%$ Tween 80 & Antimicrobial activity & $\begin{array}{l}\text { Salmonella enteritidis, Escherichia coli O157:H7, } \\
\text { and Listeria monocytogenes }\end{array}$ & 100 & $400 / 600 /-$ & $\begin{array}{l}2016 \\
{[45]}\end{array}$ \\
\hline Oregano & $\begin{array}{l}\text { Phase Inversion } \\
\text { Temperature method }\end{array}$ & Tween 80 & Anti-bacterial activity & Staphylococcus aureus, and Escherichia coli & $35-55$ & $0.5-0.6 / 0.9-3.3 /$ & $\begin{array}{l}2017 \\
{[46]}\end{array}$ \\
\hline Ginger & Ultrasonic & Tween 80 & $\begin{array}{l}\text { Anti-microbial and } \\
\text { anti-oxidant efficiency }\end{array}$ & $\begin{array}{l}\text { Salmonella Typhimurium, } \\
\text { Listeria monocytogenes }\end{array}$ & $57-163$ & $-/-/ 12-15$ & $\begin{array}{l}2018 \\
{[47]}\end{array}$ \\
\hline $\begin{array}{l}\text { Curcumin- } \\
\text { cinnamon-garlic }\end{array}$ & Homogenizer & $10 \%$ Tween 80 & $\begin{array}{l}\text { Improve the structure, } \\
\text { anti-bacterial and antioxidant } \\
\text { properties of films }\end{array}$ & $\begin{array}{l}\text { Psychrophilic bacteria, yeast and } \\
\text { mold growth }\end{array}$ & $9-130$ & - & $\begin{array}{l}2018 \\
{[48]}\end{array}$ \\
\hline Linalool & Ultrasonic & Tween 80 & $\begin{array}{l}\text { Anti-bacterial and anti-biofilm } \\
\text { activities }\end{array}$ & Salmonella Typhimurium & 11 & $60 \% /-/-$ & $\begin{array}{r}2019 \\
{[49]}\end{array}$ \\
\hline Thyme essential oil & Ultrasonic & $1 \%$ Tween 80 & Anti-microbial activity & $\begin{array}{l}\text { Salmonella paratyphi, Staphylococcus aureus, } \\
\text { Klebsiella pneumoniae, and Enterococcus. } \\
\text { faecalis/Pseudomonas luteola, Photobacterium } \\
\text { damselae, Vibrio vulnificus, Enterococcus faecalis, } \\
\text { Serratia liquefaciens, and Proteus mirabilis }\end{array}$ & 448 & $-/-/ 15-26 \mathrm{~mm}$ & $\begin{array}{l}2020 \\
{[50]}\end{array}$ \\
\hline $\begin{array}{l}\text { Origanum } \\
\text { majorana }\end{array}$ & Homogenizer & Tween 80 & Anti-fungal & $\begin{array}{c}\text { Aflatoxin B1, Aspergillus fumigatus, Aspergillus } \\
\text { luchuensis, Aspergillus niger, Penicillium } \\
\text { chrysogenum, Penicillium italicum, } \\
\text { Cladosporium cladosporioides, Fusarium } \\
\text { poae, and Alternaria alternata }\end{array}$ & $32.65-52.38$ & $2.5 /-/-$ & $\begin{array}{r}2020 \\
{[51]}\end{array}$ \\
\hline Cinnamon & Ultrasound & Tween 80 & Anti-microbial activity & Bacteria and molds & 162 & - & $\begin{array}{l}2020 \\
{[52]}\end{array}$ \\
\hline Curcumin & $\begin{array}{l}\text { Emulsion Phase } \\
\text { Inversion }\end{array}$ & Span 80 , Tween 80 & Anti-microbial activity & Escherichia coli, Staphylococcus aureus & $10-12$ & - & $\begin{array}{r}2020 \\
{[53]}\end{array}$ \\
\hline Oregano & Homogenizer & Tween 80 and ethanol & Anti-microbial activity & $\begin{array}{l}\text { Both Gram-positive and Gram-negative } \\
\text { bacteria under TVC (Total Viable Count) test }\end{array}$ & 50 & $\begin{array}{l}\text { TVC }=9.09 \log \\
\text { CFU } / g\end{array}$ & $\begin{array}{r}2020 \\
{[54]}\end{array}$ \\
\hline
\end{tabular}


Table 1. Cont.

\begin{tabular}{|c|c|c|c|c|c|c|c|}
\hline Essential Oil & Technique & Emulsifier & Functions & Microorganism & Droplet Size (nm) & $\begin{array}{l}\mathrm{MIC/MBC} / \mathrm{IZ} * \\
(\mathrm{ppm} / \mathrm{ppm} / \mathrm{mm})\end{array}$ & $\begin{array}{c}\text { Year } \\
\text { [Ref.] }\end{array}$ \\
\hline Cinnamon & Ultrasonic & $6 \%$ Tween 80 & $\begin{array}{l}\text { Improve the structure and } \\
\text { anti-bacterial properties } \\
\text { of films }\end{array}$ & $\begin{array}{l}\text { Escherichia coli, Staphylococcus aureus under } \\
\text { OD (Optical Density) measurement at } 650 \lambda\end{array}$ & 60 & $\mathrm{OD}=0.2$ & $\begin{array}{l}2020 \\
{[55]}\end{array}$ \\
\hline Lime & Magnetic stirring & 15\% Tween 80 & $\begin{array}{l}\text { Physical, morphological and } \\
\text { anti-bacterial properties }\end{array}$ & $\begin{array}{l}\text { Escherichia coli, Salmonella spp., and } \\
\text { Staphylococcus aureus }\end{array}$ & 21 & $-/-/ 8-9$ & $\begin{array}{l}2020 \\
{[56]}\end{array}$ \\
\hline $\begin{array}{l}\text { Lavandula } x \\
\text { intermedia }\end{array}$ & $\begin{array}{l}\text { Solvent displacement } \\
\text { technique + magnetic } \\
\text { stirring }\end{array}$ & - & $\begin{array}{l}\text { Evaluation of chemical } \\
\text { composition and } \\
\text { anti-bacterial activity }\end{array}$ & Escherichia coli, Bacillus cereus & 187 & $\begin{array}{c}0.01-0.37 / 0.02- \\
0.37 /-\end{array}$ & $\begin{array}{l}2020 \\
{[57]}\end{array}$ \\
\hline $\begin{array}{l}\text { Ferulago } \\
\text { Angulata }\end{array}$ & Ultrasonic & Tween 80 & Anti-bacterial activities & $\begin{array}{c}\text { Shewanella } \\
\text { Putrefaciens, and Pseudomonas fluorescence }\end{array}$ & $<100$ & $5-15 \% / 10-30 \% /-$ & $\begin{array}{r}2020 \\
{[58]}\end{array}$ \\
\hline Lemongrass & $\begin{array}{l}\text { Low energy technique } \\
+ \text { magnetic stirring }\end{array}$ & Tween 20 & disinfection & $\begin{array}{c}\text { Cladosporium xanthochromaticum, } \\
\text { Byssochlamys spectabilis, } \\
\text { Streptomyces albidoflavus }\end{array}$ & 275 & $-/-/ 12-30$ & $\begin{array}{l}2020 \\
{[59]}\end{array}$ \\
\hline Sage & Ultrasonic & Tween 80 & Anti-bacterial activities & $\begin{array}{c}\text { Enterococcus faecalis, Klebsiella pneumonia, } \\
\text { Salmonella paratyphi, Staphylococcus aureus, } \\
\text { Proteus mirabilis, Photobacterium damselae, } \\
\text { Vibrio vulnificus, Enterococcus } \\
\text { faecalis, Pseudomonas luteola, and } \\
\text { Serratia liquefaciens } \\
\end{array}$ & 59 & $\begin{array}{c}6.25- \\
12.5 / 6.25 / 12-19\end{array}$ & $\begin{array}{l}2020 \\
{[60]}\end{array}$ \\
\hline Citral & Ultrasonic & Tween 80 & Anti-bacterial activities & Salmonella enterica, and Listeria monocytogenes & $66-131$ & $\begin{array}{c}\text { TVC }=4-5 \log \\
\text { CFU } / g\end{array}$ & $\begin{array}{l}2020 \\
{[61]}\end{array}$ \\
\hline Peppermint & $\begin{array}{l}\text { high speed } \\
\text { shearing technology }\end{array}$ & 8\% (Tween-60: EL-20 = 3:1) & Anti-bacterial activities & Escherichia coli, and Staphylococcus aureus & 50 & - & $\begin{array}{l}2021 \\
{[62]}\end{array}$ \\
\hline $\begin{array}{l}\text { Minthostachys } \\
\text { verticillata }\end{array}$ & homogenizer & Tween 20 & Anti-bacterial activity & Staphylococcus aureus & 10 & $-/-/ 44.5 \%$ & $\begin{array}{l}2021 \\
{[63]}\end{array}$ \\
\hline
\end{tabular}

* IZ: Inhibition Zone, * MIC: Minimum Inhibitory Concentration, ${ }^{*}$ MBC: Minimum Bactericidal Concentration. 


\section{Short-chained Aliphatics}

\section{Terpenoids (Isoprenoids)}<smiles>CCCCCCC(=O)CC</smiles>

3-Octanone

\section{Phenylpropanoids}<smiles>C=CCc1ccc(O)c(OC)c1</smiles>

Eugenol

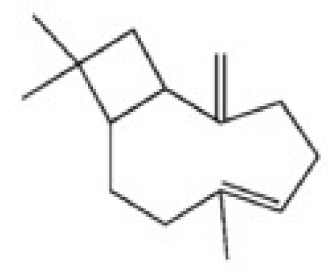

$\beta$-Caryophyllene<smiles>C=C(C)C1CC=C(C)CC1</smiles><smiles>CC12CCC(CC1=O)C2(C)C</smiles>

Camphor

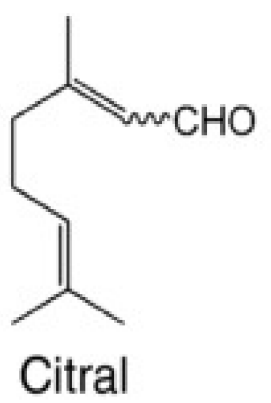<smiles>Cc1ccc(C(C)C)c(O)c1</smiles>

Thymol<smiles>CC12CCC(C(C)(C)C1)C(C)(C)O2</smiles>

1,8-Cineol

Figure 2. Typical structures of some famous EOs.

According to the hydrophobic/lipophilic nature of EOs, it can be easily postulated that anti-microbial effects of EOs is highly beholden to several properties like: their phenolic components, ability in migration, and permeability into membrane layers [38] (Table 1). This is pointed out as one of the most incentive reasons for prompt usage of EOs in food industries especially in FP purposes [64]. For instance, possible anti-microbial mechanisms involved in the intracellular and extracellular levels conducted by Origanum compactum EOs (rich in thymol) against Bacillus subtilis, has been shown in Figure 3. In detail, Origanum compactum EOs shows their anti-microbial capabilities through inhibition of Bacillus subtilis-induced biofilm formation. In other words, inhibitory effects on biofilm formation leads to an inhibited quorum sensing among bacterial cells, which have maintained the membrane integrity, and lost colony formation with minimum viability (Figure 3A). Interestingly, Bacillus subtilis are lysed when exposed and incubated in a co-culture situation with optimized concentrations of Origanum compactum [65].

Implementation of EOs, makes them as an acceptable, cost-saving, and alternatively used food additive [66] in food industries (mostly used for FP purposes of fruits, vegetables, meat, dairy, bread, and baked foods). Actually, there is commercial interest toward implemented EOs due to biodegradability in the nature of those ingredients [66], and ability in elimination of food safety risks [67]. Additionally, a majority of those well-known EOs (like: basil, bergamot, black pepper, cassia, clove, coriander, fennel, ginger, lemon, lemongrass, oregano, peppermint, rosemary, thyme, etc.), have been enumerated as Generally Recognized As Safe (GRAS) [68], that can synergistically reduce pathogenic food-borne microorganisms (phytopathogenic bacteria like: Lactobacillus, Salmonella species, and fungal species) in crops, poultry meat, yoghurt, dairy, and other food products $[34,41,69]$. 


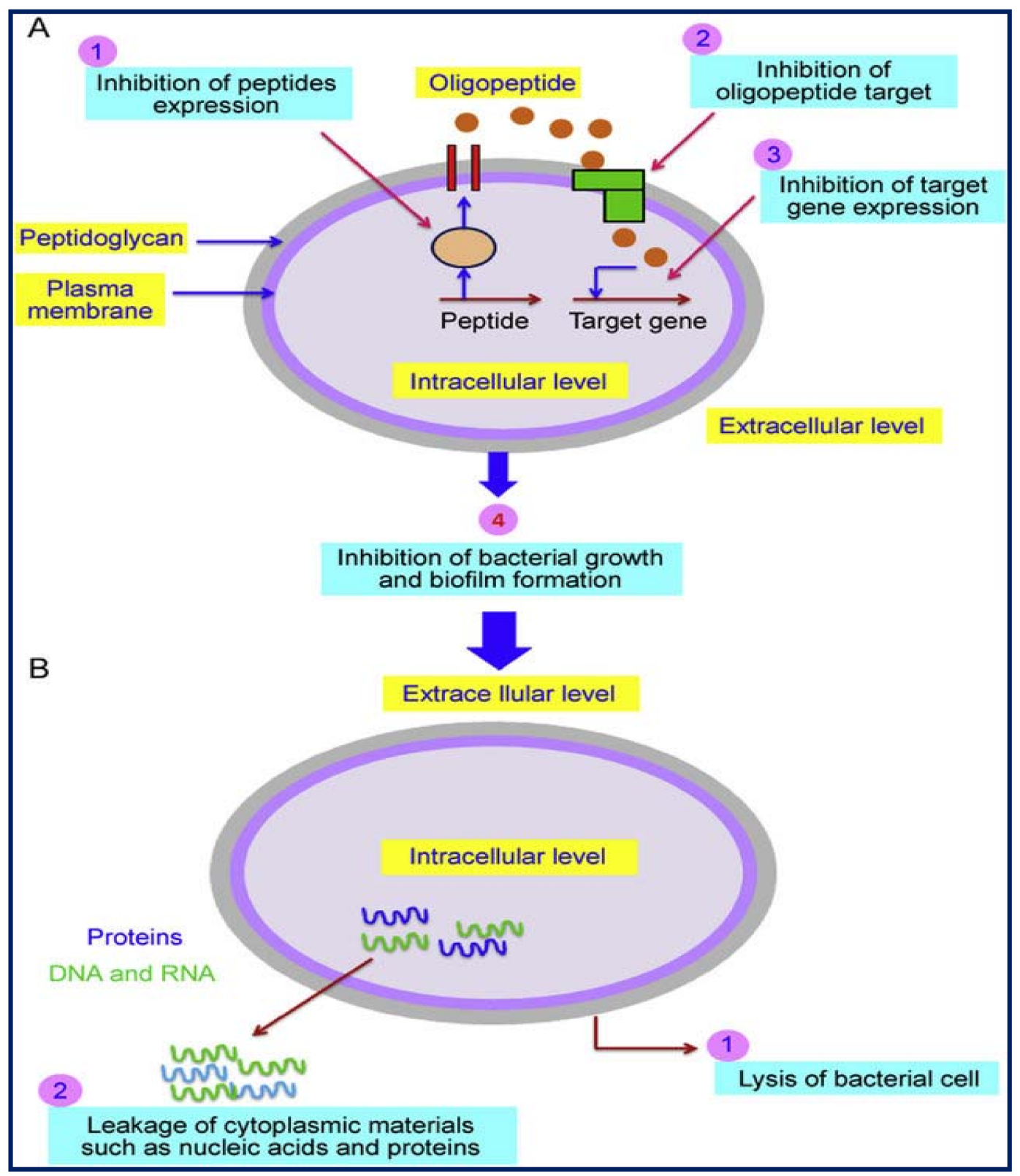

Figure 3. Anti-bacterial mechanisms of Origanum compactum EOs against Bacillus subtilis [65]. (A) Effects of Origanum compactum EOs against Bacillus subtilis through inhibition on quorum sensing. (B) Effects of Origanum compactum EOs against Bacillus subtilis through making a cytoplasmic material.

Despite previously mentioned merits, those preservative EOs cannot be directly incorporated to the food [16]. The main reason behind this point, goes back to the fact that EOs have a strong flavor. Other reasons are related to the high reactivity, remarkable hydrophobicity [70], and susceptibility of EOs to chemical conversion [37]. Other demerits of EOs that lead scientists toward combinative strategies in efficient applications of EOs, are deeply rooted in early degradation (due to interaction between volatile phase and oxidation or heating), and losing bactericidal activity after dilution (due to a significant structural change in droplets), as well [41,66].

Here, the involvement of nanotechnology based approaches in the food industry, majorly contributes to FP through providing inspiring, and acceptable perspectives for improved application of EOs like emergence of encapsulating EOs in the forms of micelles, liposomes, polymeric particles, solid lipid nanoparticles, and (nano or micro) emul- 
sions $[5,10,25,71]$. In the next paragraphs, firstly novel nanotechnology based approaches with indispensable roles in improving FP are introduced.

\subsection{An Evolutionary Era for Emerging of Nanotechnology Based Approaches in FP}

\subsubsection{Employed Forms of Essential Oils in FP}

Currently, there is a general categorization for application of nanotechnology based strategies in FP including: nanomaterial added as food ingredients for food processing, nanosensing, and nano-enabled packaging [72]. Hence, regarding the food compatibility, and easy dispersion in growing regions of microorganisms, there are several strategies being enumerated as easiest, cheapest, the most efficient, and the most environmentallyfriendly solutions for increasing industrial efficacies of EOs [73,74].

Encapsulation is mostly consisted of a process that encloses small particles for entrapping functional compounds into carriers. Incorporated EOs in the forms of biodegradable films $[66,74]$ can be utilized as separating layers into coatings, or as a thin layer of edible material applied onto the surface of food through dipping or drenching [75,76]. In addition, incorporated EOs can be recruited as biodegradable films combined with other types of edible films (such as polysaccharide, lipid, and protein-based ones with a thickness of less than $0.3 \mathrm{~mm}$ ). These are the most well-known approaches for increasing industrial and biological efficacies of EOs through nanotechnology based approaches $[77,78]$.

Accordingly, there are other advantages attributed to the usage of encapsulation in FP. It has been ideally demonstrated that encapsulation processing can preserve EOs from dire effects of any limiting agents like: photodegradation, excessive moisture, and temperature [79]. Those additional benefits include: ability in transferring lipophilic compounds in diet (as an active carrier) [31], controlled release of active compound (under specified moisture, pressure, or heat) [80], high physical durability, high oral bioavailability, giving food and beverage a high visual transparency (optical clarity) [81], increased bioactivity, rapid penetration, optimized functionality, and increased digestibility [82]. Encapsulation can make more improvements in food safety, barrier properties against gases and water, an improved diffusion, and anti-microbial activities due to wetting ability of emulsifiers $[17,25,40,66]$.

Although these aforesaid benefits of encapsulation fade away the shortcomings of EOs used in FP, researchers have controversial concepts on incorporation of coating material into fresh vegetables or fruits due to strong flavor or high toxicity in prolonged time [83,84]. To solve this problems, wide range of studies have been focused on investigating antimicrobial roles of biopolymer films through incorporation of EOs in the form of edible films) into food based products. Edible films have been applied as a thin layer of film or coating, surfaced on food with no detrimental effects on health system. To differentiate them, those layers which are formed directly on the food surface, they will be renamed "edible coatings". Whereas, if they are separately wrapped on food surface, they will be called "edible films" [74,85-87]. The reason behind incorporation of EOs in the form of edible films with FP purposes, goes back to an increasing demand for food products especially fresh-cuts of sliced fruits, and vegetables without usage of any chemical additives. Unquestionably, anti-microbial, anti-oxidant, anti-browning, and texture enhancer properties related to coating material used in EOs, fulfill those consumer's expectations, and industrialists' demands all over the world [88,89].

As a salient example, in an experimental study conducted by Azadbakht et al., antimicrobial properties of chitosan films containing Eucalyptus globulus against Salmonella enteritidis, Staphylococcus aureus, Bacillus cereus, and Escherichia coli was investigated aimed at packaging of sliced sausages, as an active bio-carrier. Results of their study showed that administration of chitosan films containing 1.5\% Eucalyptus globulus in liquid phase, induced the highest log reduction for all mentioned bacterial pathogens, introducing this strategy as a promising approach for reduction in food-borne pathogens in FP [90].

Successful reports from an experimental study carried out by Perdones et al., aimed at investigation of anti-fungal effects of chitosan-lemon EOs coating in storage stages of 
strawberries for 7 days at $20{ }^{\circ} \mathrm{C}$, resulted in significant modification in the typical fruit aroma composition and flavor. It is worthy to mention that chitosan-lemon EOs coating could postpone ripening because of reduced respiratory rate, without any negative impact on organoleptic properties of strawberries [91]. Here, in case of fruits, there are more promising results. Botrytis cinerea (causing gray molds in fruits planted in tropical regions), is considered as one of the mostly found fungi in fruits, that is of high significance in FP. Results from several researches approved anti-microbial and anti-fungal effects of thyme and oregano EOs in prolongation of shelf life in foodstuff such as fruits [92-94].

In another recently conducted study, Shubham Sharma et al. investigated inhibitory effects of Poly (lactide)-Poly (butylene adipate-co-terephthalate) (PLA-PBAT) film incorporated into the thyme and clove EOs on biofilm production, and growth of microorganisms (Escherichia coli, and Staphylococcus aureus). Interestingly, they reported that the aforesaid film incorporated into both EOs, prominently reduced biofilm production by both bacteria. Complete inhibitory effects of those films incorporated into clove EO was observed on Staphylococcus aureus from $6.5 \log \mathrm{CFU} / \mathrm{mL}$ to $0 \log \mathrm{CFU} / \mathrm{mL}$. Totally, in case of UV blocking properties, antimicrobial activity, and tensile strength, results of this study introduced PLA-PBAT films incorporated with clove EOs as an efficient approach in active FP [95].

In upcoming parts, practical applications of nanoemulsions in as other efficient type of nanotechnology based approach are discussed below.

\subsubsection{Emergence of Nanoemulsions in Food Packaging}

Along with recent developments in nanotechnology based methods, interest of food scientists has been moved toward usage of nanoscience or nanotechnology, which has turned into the call of the century, through disperse systems (as stable isotropic colloidal systems) for increasing biodegradability and long-term stability in FP $[27,96,97]$. In this approach, normally food grade ingredients (lipophilic active ingredients integrated into aqueous-based systems) are used for formulation of emulsifiers through various food engineering processes $[98,99]$. Speaking on food engineering processes, it has been implied to all methods aimed at food preservation and stabilization through food processing, evaporation, freezing, three-dimensional food-printing, pasteurization and FP [98,99].

\subsubsection{What Are Nanoemulsions?}

The aim of those recently conducted approaches in the development of nanocomposites in $\mathrm{FP}$, is incorporation of lipophilic EOs into hydrophilic material through emulsification approaches [98-101]. Emulsions (as lyophobic colloidal system) are categorized into coarse emulsions, microemulsions, and NEs (based on droplet size and stability) $[41,75,102]$.

For formulation of NEs, we need to two phases. Actually, immiscible liquids, and an emulsifiers synergistically make aqueous phase of NEs (equivalent to polar solvent like water, and a co-solvent like carbohydrates, protein, and alcohol (Table 1)) $[89,100,103]$.

NEs are made of triacylglycerols, diacylgycerols, monoacylglycerols, and free fatty acids as the oil phase, water (aqueous phase), and plus to surfactants. In this case, usage of emulsified EOs in nanometric scales (known as NEs), are designed and classified into three main classes: Oil-in-Water $(\mathrm{O} / \mathrm{W})$, Water-in-Oil (W/O), and bi-continuous delivery systems [104]. According to the main classification, there are two subgroups involving multiple emulsion systems in the forms of: Water-in-Oil-in-Water $(\mathrm{W} / \mathrm{O} / \mathrm{W})$, and Oil-inWater-in-Oil (O/W/O) [105].

Those $\mathrm{O} / \mathrm{W}$ systems include aqueous continuous phase for delivering lipophilic vitamins, carotenoids, and polyunsaturated fatty acids $[9,15,80]$, consisting of small and immiscible lipid droplets dispersed in surfactant below 100 nanometer $(\mathrm{nm})$ (range of 10-100 nm, but can be attributed to $1-500 \mathrm{~nm}$ ) as an aqueous medium. In addition, NEs in the form of $\mathrm{O} / \mathrm{W}$ can be recruited for delivery of hydrophobic active compounds $[27,89,100]$.

NEs in the form of W/O delivery systems consist of small water droplets dispersed in oil medium. They can be recruited for delivery of hydrophilic active compounds [104-106]. 
The third main class of delivery systems are bi-continuous delivery systems, consisting of interdispersed microdomains of oil and water $[104,105]$.

These systems compromise drawbacks of EOs, and introduce advantages like: decreased compound dosage, increased surface area, high mechanical strength, targeted delivery, optimizing chemical interactions with food ingredients (food matrix), high surfaceto-volume ratio by small particle size, and long-lasting survival rate without phase separation [107-114].

There are other competencies in NEs to make EOs more efficient in FP. NEs are not thermodynamically stable (but kinetically stable), and are not physically or chemically affected by $\mathrm{pH}$ [81]. However, incorporation of emulsions (acting as stabilizers) majorly contributes to improvement of kinetic stability in NEs. In case of visual appearances, they are translucent or milky, but may be affected by coagulation of droplet size enhancement [81].

Interestingly, due to Brownian motions, NEs show an acceptable and long-lasting stability against gravitational forces, creaming, sedimentation, and flocculation [115]. Emulsifiers such as surfactants (Tween 20, Tween 80, span 20, span 80), amphiphilic polysaccharides or proteins, and phospholipids are essential molecules for industrial formulation of NEs. The needed amount of the aforesaid emulsifiers for formulation of NEs, is less than the ones needed for formulation of conventional emulsions [27,41,100]. In total, the type of used emulsifiers added in food ingredients, and type of their fabrication can highly influence mechanistic interactions of NEs with cell membrane, surface charge, droplet size, and their anti-microbial properties $[107,108,116]$. Practically, NEs in droplet size are widely used in a wide range of industries as FP majorly due to the rheological behaviors like: optical properties and stability (according to their droplet size compared to microemulsions), and specific diffusion [107]. So, it seems that utilization of NEs can provide commercial, and technological opportunities in industries especially FP purposes [117]. Recently, according to the successful results of a wide array of studies on various types of foods (especially fish, vegetables, and poultry meat), NEs have been widely served for encapsulation of EOs, and alternatively considered as one of the most efficient delivery systems in food industry with FP purposes [118]. In the following paragraphs, several recently conducted researches using various types of NEs for FP purposes are reviewed.

One experimental study aimed at investigation of Pistacia khinjuk extract based NEs in the form of coatings on shelf life of sunflower oil, reported the highest stability of Pistacia khinjuk extract based NEs coated with gum seeds of Balango during a 24-day storage in $60{ }^{\circ} \mathrm{C}[119]$.

Another experimental study aimed at investigation of bergamot EOs-based NEs (with approved preservative and anti-cancerous effects on food), they analyzed dispersibility in water and anti-microbial activities of bergamot EOs-based NEs. Results of this study introduced these bergamot EOs-based NEs with therapeutic effects as anti-cancerous (against Caco-2 cells), and anti-microbial properties (against Escherichia coli, Lactobacillus delbrueckii, and Saccharomyces cerevisiae) in comparison with free oil [120].

In another comparative experimental study, researchers investigated anti-microbial properties of a blended EOs and their NEs conducted on Clostridium sporogenes inoculated in Mortadella based meat product. They reported more efficacy in NEs than free EOs. Significant anti-oxidant properties were observed in combination of NEs with their EOs. To some considerations, it is of high importance to choose anti-oxidant compounds compatible with materials used in active FP, and with food ingredient in order to make a homogenous distribution [121].

Other studies have been focused on a variety of novel EOs. A comparative study was done on grapefruit peel based EOs and their NEs on reduction of food-borne pathogens load (Staphylococcus aureus, Enterococcus faecalis, Klebsiella pneumonia, and Salmonella paratyphi A) in fish based foodstuff (Mackerel, Sardine, Anchooy, and Rainbow trout). Results of this study approved bacteriostatic effects of mentioned EOs, and more bacteriostatic potency when they were incorporated into their NEs [122]. In summary, it seems that more precise and 
improved formulation of NEs can stimulate bactericidal effects of NEs in order to increase efficiencies of FP.

\subsection{An Introduction to Various Techniques Used for Preparation of Nanoemulsion in Food Packaging Purposes}

There is a wide array of specific preparation methods for NEs. Generally, they are divided into two categories as low-energy, and high-energy methods according to the energy requirements $[32,123]$. This common classification will be important when we encounter with disadvantages related to preparation or formulation of NEs that need high concentrations of synthetic surfactant, as mentioned earlier [103,113,124].

The low-energy based methods are basically classified into two categories including: thermal and non-thermal approaches. As it is clear from the nomination, preparation of NEs in non-thermal approaches is done through making changes in the composition, leading to spontaneous emulsification (including a hydrophobic oil, a hydrophilic emulsifier, organic solvent, and water), and emulsion phase inversion [117,118,123]. Whereas, in thermalbased methods, preparation of NEs is done through making changes in the temperature (or changing in electrical charge and $\mathrm{pH}$ ), leading to phase inversion temperature (changes in temperature leading to make a shifting the emulsifier affinity from one phase to the other, and making more stable emulsion) or phase inversion composition (changing the composition at constant temperature during emulsification procedure) $[89,103,124]$.

The high-energy based methods majorly include: high shear stirring, rotor-stator emulsification, ultrasonic emulsification, high-pressure valve homogenization, microfluidics, and membrane emulsification. The main goal in high-energy based methods for preparation of NEs, is rupturing oil and water to produce small droplet. In case of energy, mechanical disruptive forces such as: tension, turbulence, and cavitation, all provide high levels of energy for mixing aqueous and oil phases. In contrast, the majority of energy resources in low-energy based methods for preparation of NEs, are provided by physicochemical processes $[103,113,124]$.

For preparation of NEs based delivery systems, it is of great importance to qualitatively investigate several characteristics as: stability, chemical composition, physical properties, droplet size, phase transition (if possible), nanostructures, consistency, quality, and morphology [125]. Those investigations can be easily done through multiple methods like: Light scattering, Transmission Electron Microscopy (TEM), Scanning Electron Microscopy (SEM), Atomic Force Microscopy (AFM)), Field Emission Electron Microscopy (FESM) [126-128], X-ray Diffraction (XRD) [129], infrared spectroscopy, differential scanning calorimetry, and dynamic light scattering. These mentioned approaches and tools are the most recruited approaches for qualitative investigation of structures in fabricated NEs based delivery systems $[89,103,124]$.

Emergence of Ultrasonic-Based Approaches as an Efficient Trend in Food Packaging

Over the past few decades, there is an arising interesting on the industrial applications of ultrasonic approaches in food industries, FP, and food processing purposes (especially in ready-to-eat fresh food). This point is accentuated due to making permanent physical, chemical, and barrier (mechanical) changes for retaining of quality, and refraining from loss of nutrients through non-thermal approaches through usage of ultrasonic approaches. Hence, ultrasonic technology has been emerged as a promising approach with ability for microbial protection, and keeping nutritional value of the food [130-132].

From physical aspects, ultrasonic-based approaches are basically comprised of tools using vocal waves exceeding hearing threshold of human beings (at least more than 16,000 cycles per second $(16 \mathrm{kHz})$ ). Physically, those tools convert electrical energy to acoustic energy (vibrational, non-ionizing, non-invasive, non-destructive, and non-polluting form of mechanical energy) by energy transducer (Figure 4A) $[130,132,133]$. This process is aimed to produce smaller and more stable $\mathrm{O} / \mathrm{W}$ dispersions with acceptable distribution for preparation of NEs used in research purposes in food industries [134,135]. As it has been mentioned earlier, the main strategy served in ultrasonic-based approaches is 
making strong shearing, and mechanical disturbing forces. This aim comes true by usage of high-intensity waves, being resulted in making droplets in decreased size without any extra need to other requirements for preparation of NEs, and with improvement in mass transferring [136-138].

A

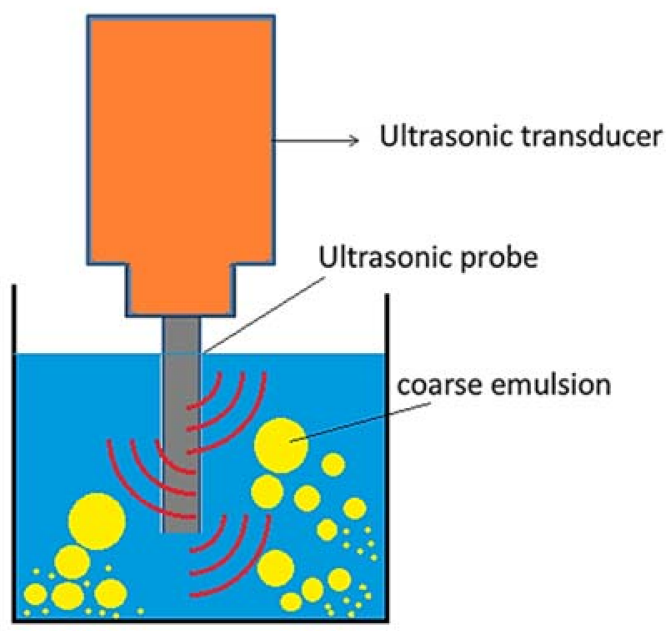

B

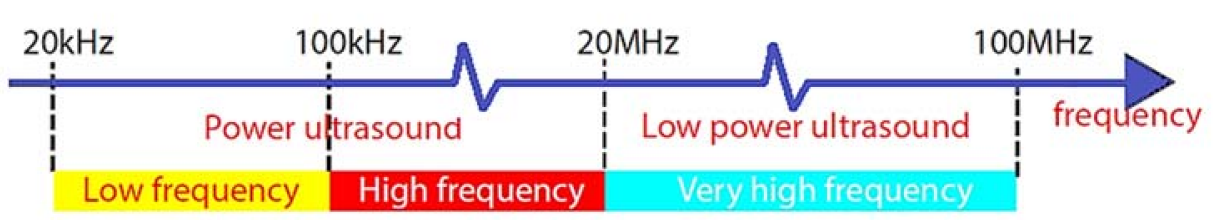

Figure 4. (A) Ultrasonic system broke the larger drops, and create micro/nano droplets. (B) The classification of the ultrasonic-based on the power.

From the lowest to highest levels of frequencies, ultrasonic-based technologies can be classified into two groups: power ultrasound, and low power ultrasound. Power ultrasound comprises lower frequency and higher intensity (high power). While, low power ultrasound include very high frequency (Figure 4B) [134,135,139]. Criteria that are supported by ultrasonic-based technologies are as following: agitation, vibration, pressure, shock waves, shear forces, microjetting, compression and sparseness, acoustic flow, cavitation, and free radical formation. Among them, several physical phenomena are provided in lower levels of frequencies, and chemical phenomena are provided in a higher range of frequencies [140]. To be more precise, ultrasonic-based technologies that are recruited in FP industries are power ultrasound-based methods, supporting changes in physical phenomenon like cavitation (namely process of producing bubbles by ultrasonic-based methods) [131,141], leading to compacting liquid phase of medium, oscillation of cavitation bubbles, bursting, and making an environment with high range of temperature/pressure. The fabricated NEs by ultrasonic-based methods, regularly depict thermal stability [138], and acceptable anti-microbial/anti-oxidant activities [136].

With a precise look, development of ultrasonic-based approaches in food industries, and FP is beholden to a variety of advantageous properties. Those features generally include abilities in disinfection as making a reduction of pesticides residues in vegetables/cereals/fish/and fruits, and refraining from excessive usage of chlorine dioxide due to their carcinogen activities) $[136,137,142]$. Additionally, ultrasonic-based approaches make a sterilized environment (especially due to cavitation in high temperature, and pressure, leading to damaged microbial cell wall, and production of free radical reaction), and induce enzymatic inactivation for killing microorganisms (due to protein denaturation, contribution of free radicals with amino acid residues). Ultrasonic-based approaches have 
abilities in desensitization of allergens (like peanuts and shrimps by making changes in configurational structures), dehydration and swelling (by mechanical changes on surface tensions leading to cell wall rupturing), and curing (especially for prolongation in shelf lives of meat, improvement in their color/flavor by reduction in curing time, and rapid mass transferring of $\mathrm{NaCl}$ ) [143-145].

Acoustic forces used for acoustic separations in ultrasonic-based approached are rapid, non-contact, and gentle, when compared with conventional filtering. Those unique features lead to make a high energy efficiency, acceptable emulsion stability, and easy-to- operate strategy in food purposes [131,138,145].

As there is a great interest on the usage of ultrasonic-based methods in FP, there is a wide range of experimental (in vitro) studies prepared by ultrasonic methods, aiming at characterization and formulation of EOs-based NEs, and evaluating anti-bacterial effect of those EOs-based NEs on food-borne pathogens [146,147] (Table 2).

Results from one study showed that the prepared NEs from saffron EOs under sonication process, showed potential effects on enhancing the shelf life of shrimp by controlling the growth of microorganisms, oxidative activity, and $\mathrm{pH}[148,149]$.

There are a wide array of studies conducted like those aforesaid studies. Accordingly, results of previous studies suggest that comprehensive understandings on the potentiated mechanisms related to anti-microbial effects of EOs-based NEs, and even on characterization or fabrication can effectively lead to more industrial engineering on various types of ultrasonic methods $[22,150,151]$. With specified and adjusted amplitude, nominal power, temperature, time, acoustic vibration [152-156], inert material used in probes (the ones with no corrosion), and frequency in ultrasonic-based methods [152-158], we can deduce that coarse emulsions can be subjected into the most qualified, highly translucent, highly stable, and feasible EOs-based NEs $[47,154,155,159]$. In this situation, those EOsbased NEs with highlighted features, play indispensable roles in prevention from food spoilage in storage processes, food preservation, assurance of food safety, and prolongation of shelf life $[25,116,143,160]$. The most significant advantages related to application of ultrasonic-based methods like ultrasonic-based emulsification in FP, which delivered in various systems (as film-based or coating-based systems), provide anti-bacterial, anti-fungal, anti-oxidant effect, barrier (mechanical) properties [47,152-159,161].

In a research done by Gul et al., [158] the effect of the ultrasonic-based techniques on clove EOs-based NEs, and hazelnut meal protein has been studied. In this study, one index called Polydispersity Index (PDI) (describing width or spread of the particle size distribution, and analyzed by etasizer Nano ZS laser diffractometer) decreased with increasing trend in time. The amount of amplitude did not affect this trend, but with increasing amplitude, in similar time periods, the PDI index decreased (Figure 5A). Regarding the size of nanoparticles, the diameter of nanoparticles decreased with increasing test time. For example, at $50 \%$ amplitude, increasing the time from $2 \mathrm{~h}$ to $6 \mathrm{~h}$ reduced the nanoparticle size from $247 \mathrm{~nm}$ to $201 \mathrm{~nm}$. It was also reported that elongation of the sonication time results in smaller nanodroplets [157]. However, prolongation in the process time cause the over-processing or may degrade the bioactive compounds [162]. Increasing the amplitude had a direct effect on reducing the size of the nanoparticles, so that increasing the amplitude from 50 to 100 reduced the size of the nanoparticles from $247 \mathrm{~nm}$ to $184 \mathrm{~nm}$ (Figure 5B). It was also shown that existence of an increasing trend in ultrasonic power (energy), has a significant effect on reducing the size of nanoparticles. This effect was exacerbated at high amplitudes (Figure 5C). The final NEs prepared by ultrasonic techniques under different conditioned, depicted different impact of the prepared film for FP purposes. It was revealed that the lowest Water Vapor Permeability (WVP) belonged to the ones which were under higher energy, higher amplitude, and the longest process time (Figure 5D). 
Table 2. Summary of the previous studies using ultrasonic technique to prepare nanoemulsion.

\begin{tabular}{|c|c|c|c|c|c|c|c|c|c|}
\hline EOs & Time & Temp. & $\begin{array}{l}\text { Energy/ } \\
\text { Frequency }\end{array}$ & $\begin{array}{l}\text { Droplet } \\
\text { Size (nm) }\end{array}$ & $\begin{array}{c}\text { Zeta } \\
\text { Potential }(\mathrm{mV})\end{array}$ & PDI * & $\begin{array}{l}\text { Packaging } \\
\text { Type }\end{array}$ & Consequences & $\begin{array}{l}{[\text { Ref] }} \\
\text { Year }\end{array}$ \\
\hline $\begin{array}{l}\text { Oregano } \\
\text { (Origanum } \\
\text { vulgare) }\end{array}$ & $10 \mathrm{~min}$ & $25^{\circ} \mathrm{C}$ & $400 \mathrm{~W}$ & $180.59 \pm 84.76$ & - & 0.220 & Film & $\begin{array}{l}\text { Increased bioavailability, less preservative content might be used } \\
\text { and still deliver the same anti-microbial efficiency if encapsulated } \\
\text { in smaller particles. }\end{array}$ & $\begin{array}{l}{[163]} \\
2014\end{array}$ \\
\hline $\begin{array}{l}\text { Clove Bud } \\
\text { (Syzygium } \\
\text { aromaticum) }\end{array}$ & $10 \mathrm{~min}$ & $25^{\circ} \mathrm{C}$ & $400 \mathrm{~W}$ & $250.43 \pm 100.67$ & - & 0.162 & Film & $\begin{array}{l}\text { Increased bioavailability, less preservative content might be used } \\
\text { and still deliver the same anti-microbial efficiency if encapsulated } \\
\text { in smaller particles. }\end{array}$ & $\begin{array}{l}{[163]} \\
2014\end{array}$ \\
\hline $\begin{array}{l}\text { Zataria } \\
\text { multiflora }\end{array}$ & $6 \mathrm{~min}$ & $50^{\circ} \mathrm{C}$ & - & - & - & - & Coating & $\begin{array}{l}\text { A significant difference in mean bacterial count between the study } \\
\text { groups during } 12 \text { days of storage. } \\
\text { Significant reduction in initial count of E. coli O157: H7) from } 6.69 \\
\quad \pm 0.13 \log \text { CFU /g, -to } 4.06 \pm 0.15 \log \text { CFU /g) }\end{array}$ & {$[164]$} \\
\hline $\begin{array}{l}\text { Sour lemon } \\
\text { peel }\end{array}$ & 10 & $25^{\circ} \mathrm{C}$ & $24 \mathrm{kh}$ & 150 & - & - & Coatings & $\begin{array}{l}\text { Significant improvement in their physicochemical, textural and } \\
\text { sensory characteristics compared to the control during 12-day } \\
\text { cold-storage. }\end{array}$ & $\begin{array}{l}{[165]} \\
2019\end{array}$ \\
\hline Hazelnuts & $2-4-6 \min$ & $25^{\circ} \mathrm{C}$ & $750 \mathrm{~W}$ & $201-247$ & $-32 \pm 6$ & $0.3 \pm 0.2$ & Film & $\begin{array}{l}\text { Given the films anti-bacterial activity against } L \text {. monocytogenes, } B \text {. } \\
\text { subtilis, S. aureus, P. aeruginosa and E. coli, and antioxidant activity }\end{array}$ & $\begin{array}{l}{[158]} \\
2018\end{array}$ \\
\hline Geranium EO & $2 \mathrm{~min}$ & $25^{\circ} \mathrm{C}$ & $65 \mathrm{~W}$ & $13-15$ & - & 0.06 & Coating & $\begin{array}{l}\text { Enhance the toxicity of geranium EO against larvae of Culex } \\
\text { pipiens pipiensand Plodia interpunctella }\end{array}$ & $\begin{array}{l}{[166]} \\
2020\end{array}$ \\
\hline Ginger & $5 \mathrm{~min}$ & $25^{\circ} \mathrm{C}$ & $160 \mathrm{~W}$ & 236 & - & - & Coating & $\begin{array}{l}\text { Efficient delivery system for the improvement of Jujube } \\
\text { fruit quality }\end{array}$ & $\begin{array}{l}{[129]} \\
2020\end{array}$ \\
\hline Wheat germ oil & $10 \mathrm{~min}$ & $25^{\circ} \mathrm{C}$ & $\begin{array}{c}60 \% \\
\text { amplitude }\end{array}$ & 114 & -14.7 & 0.14 & Coating & Oil stability at $4 \mathrm{C}$ & {$[168]$} \\
\hline Lemon oil & $1 \mathrm{~min}$ & $25^{\circ} \mathrm{C}$ & $\begin{array}{c}70 \% \\
\text { amplitude }\end{array}$ & 120 & - & - & Coating & Comparing with other methods & $\begin{array}{l}{[169]} \\
2011\end{array}$ \\
\hline Eucalyptus oil & $5-30 \mathrm{~min}$ & $25^{\circ} \mathrm{C}$ & $750 \mathrm{~W}$ & $50-10$ & - & - & Film & Anti-bacterial activity against Staphylococcus aureus & $\begin{array}{l}{[170]} \\
2014\end{array}$ \\
\hline $\begin{array}{l}\text { Zataria } \\
\text { multiflora }\end{array}$ & $2.5-10 \mathrm{~min}$ & $25^{\circ} \mathrm{C}$ & $150 \mathrm{~W}$ & $168-91$ & - & - & Film & Extending the shelf life of food & $\begin{array}{l}{[171]} \\
2019\end{array}$ \\
\hline Thymol & $10 \mathrm{~min}$ & $20^{\circ} \mathrm{C}$ & $700 \mathrm{~W}$ & $150-250$ & - & $0.2-0.15$ & Film & Antifungal effect in cherry tomatoes & $\begin{array}{l}{[172]} \\
2018\end{array}$ \\
\hline Saffron & - & - & - & - & - & - & - & - & - \\
\hline
\end{tabular}

* PDI: Polydispersity Index. 


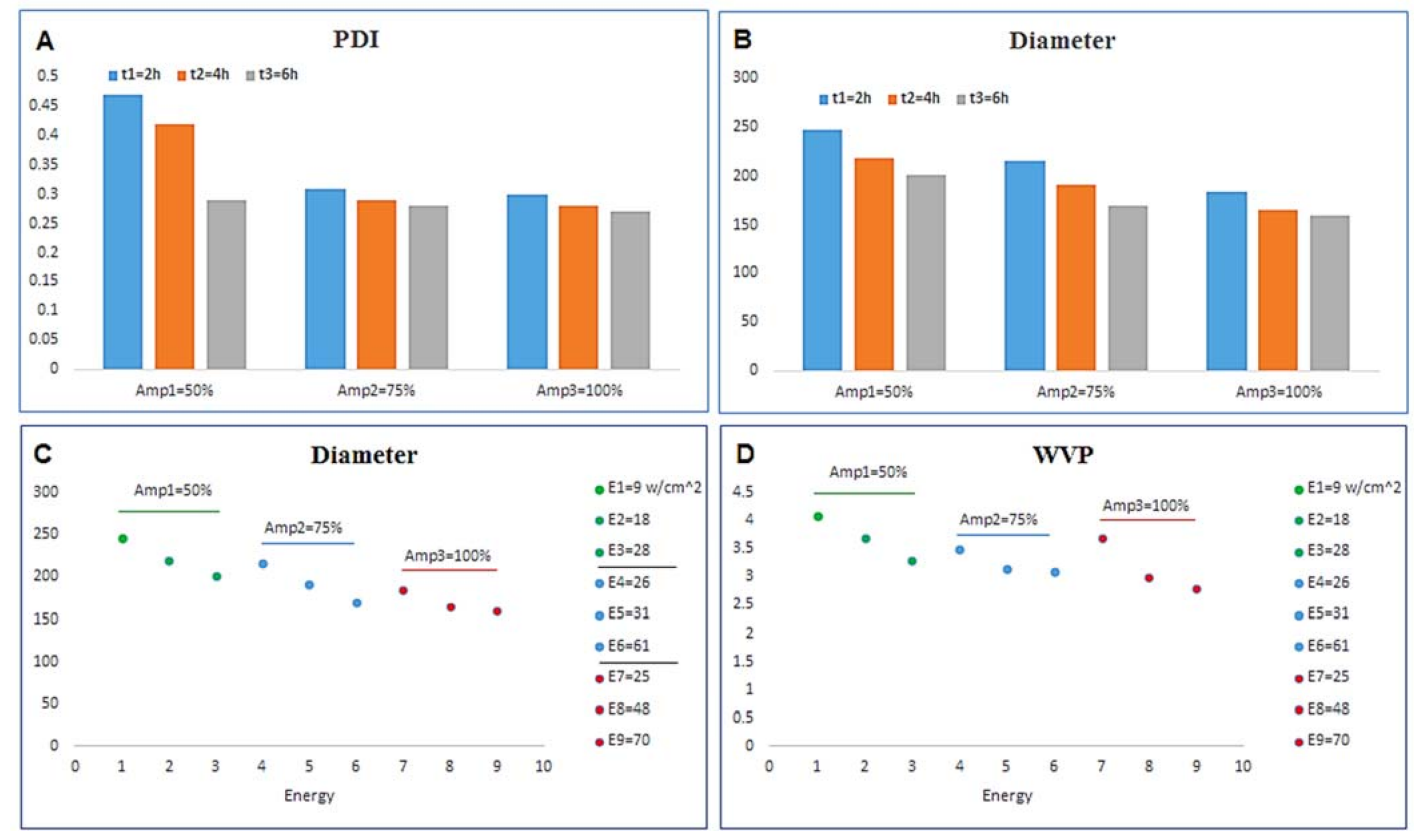

Figure 5. (A) Changes in PDI index under different conditions including time and amplitude. (B) Changes in nanodroplets diameter under different conditions including time and amplitude. (C) The impact of energy on diameter of nanodroplets under different conditions including time and amplitude. (D) Changes in the WVP of the prepared films under different conditions.

In another research, it was reported that the final size of the nanodroplets depends on the various parameters including sonication time, optimum power, ultrasonic probe distance and, cycle [166] (Table 2). Optimum power was studied as the main parameter to minimize energy waste, and efficiently diminishes costs of production on an industrial scale. In case of troubleshooting, it is unnecessary to use more power beyond the optimal point, because it consumes extra energy without significant efficiency. Therefore, in this study, the maximum power for the next experiments, was proved to be 65 watts. Of course, this capability does not necessarily apply to all NEs, and in each study, the need for optimization based on the diameter of the nanoparticles is highly recommended [166]. The cycle ("on/off" pulse) was considered as another important parameter, since this pulse alter the droplet size. During the pulse, amount of cavitation bubble grow, while they decrease when the pulse is "off" [141].

In a nanotechnology-based comparative and experimental study using ultrasound homogenizer approaches, anti-microbial properties of anise seed extract-based NEs, and bulk extract on pathogenic bacteria (Escherichia coli, Pseudomonas aeruginosa, Salmonella typhimurium, Yersinia enterocolitica, Bacillus cereus, Staphylococcus aureus, Listeria monocytogenes), were investigated. After physicochemical analyses on NEs, determination, and confirmation of droplet size, they reported significant anti-bacterial features from anise seed extract-based NEs when compared to bulk extract. They introduced anethole, naringenin, and taxifolin as the most phytochemical phenolic compounds in anise seed extract-based NEs [173]. They concluded that ultrasound-based methods will be suggested as a promising, economic, feasible, and stable approach for aromatic NEs formulation, and fabrication with ability to monitor quality of the surfactant in NEs in FP industries.

In another nanotechnology-based comparative and experimental study using ultrasound homogenizer approaches, anti-microbial properties of thyme EOs-based NEs on pathogenic bacteria (Escherichia coli O157:H7), was investigated on cherry tomatoes. After determination and confirmation of droplet size, mentioned NEs were formulated through ultrasonic methods. They reported a remarkable increase in anti-bacterial effects 
of thyme EOs-based NEs in comparison with coarse emulsions by a significant reduction in bacterial population $(\log \mathrm{CFU} / \mathrm{g})$, without destructive effects on appearance of cherry tomatoes (color and firmness), and with significant anti-bacterial effects on wastewater for washing food products [174]. They concluded that thyme EOs-based NEs made by ultrasonic approaches, synergistically helped to improve the anti-bacterial effect of thyme EOs, reduced surface attachment of Escherichia coli O157:H7 on cherry tomatoes, induced decontamination of wastewater, and retained quality characteristics of cherry tomatoes.

In another study conducted on atmospheric packaged fresh-cut cucumber, aimed at investigation of ultrasound modification on anti-microbial properties, and quality of storage in refrigerator, results showed inhibition from growth of yeasts and molds colonies, reduction in loss of firmness, lowering water mobility without damage in cell wall integrity, and decline in total color change [175]. They demonstrated that ultrasonic method had a contributing role in increased preservation of fresh-cut cucumber packaged with polystyrene, and sealed with polypropylene film.

In a comparative experimental study, authors demonstrated successful results of ultrasound based sterilization approaches which affect shelf life and storage of fruits, and vegetable juices in comparison with other conventional thermal strategies. In this novel study, researchers used crude extract of orange peels-based EOs, and a combination of ultrasound with ultraviolet irradiation approaches for their fabrication. Anti-microbial effects were established by a five log reduction in microbial growth after ultrasound treatment. There were improved quality characteristics (including: brix, titratable acidity, $\mathrm{pH}$, salt, and conductivity) in vegetable juices compared with thermally-processed juice samples, and untreated samples [176]. Hence, they proposed a simultaneous combination of thermal approaches, and ultrasonic-based approaches for maintenance of microbial safety, improvement in quality parameters, and the most enhanced shelf life.

In another comparative experimental study done by Jiajia Rao et al., they conducted several different approaches as preparation of colloidal dispersions as: thermal treatment; high shear mixing; high pressure homogenization; and sonication, in order to evaluate effects of fabrication and composition types of lemon oil-based NEs, microemulsions, and emulsions on establishment of the most stable approach in FP, and food-grade delivery system. They demonstrated that usage of a combinative method involving: high energy homogenization (high pressure or ultrasonic homogenizer) or low energy homogenization (heating) efficiently suffice for formation of EOs-based NEs at low or intermediate surfactant-to-oil ratio [169]. They believed that results of such studies can provide efficient insights into designating the most stable EOs-based food-grade colloid dispersion in FP.

As it had been reviewed earlier, some food scientists and industrialists have focused on anti-fungal properties of EOs-based NEs in research purposes. Results of one experimental study, investigated anti-fungal effects of Zataria multiflora Boiss-based NEs, and Carum copticum $L$ on Byssochlamys fulva (as a heat-resistant fungi leading to fruit spoilage) in apple juice. From each EOs, NEs were prepared through ultrasonic-based methods. They presented significant anti-mold reduction in that type of fruit based beverages [26].

Unquestionably, insecticide features of some herbal EOs-based NEs are of high industrial prominence, especially for agriculturalists. One experimental study investigated insecticide effects of Geranium maculatum L.-based NEs made by ultrasonication against the growth of larvae of Culex pipiens pipiens, and Plodia interpunctella. Results of this study reported twofold increase in insecticide abilities of mentioned EOs-based NEs with prolonged stability in $25^{\circ} \mathrm{C}$ [166]. Those results are considered promising enough to be extensively used in FP.

In another study, researchers investigated whether Origanum vulgare L.-based NEs which were prepared by ultrasonication could be added as food additives for prolongation in shelf life, or conventional emulsions could play a contributing role to reach in this goal. They evaluated anti-fungal, and anti-bacterial effects of mentioned EOs-based NEs on Candida albicans, Aspergillus niger, and Staphylococcus aureus. There was a great anti- 
microbial ability found in Origanum vulgare L.-based NEs, compared with coarse emulsions, introducing them as acceptable food additives for prolonged shelf life [21].

It seems that in FP, there is a great concern about prolongation of shelf life for the fish or fishery products in storage processing, due to providing a healthy and balanced diet enriched with amino acids/fatty acids. Additionally, as there is a growing demand on fisheries among consumers, prolongation of shelf life for those foodstuffs is of economic and marketing importance. As in one comprehensive comparative study, the role of EOs-based NEs prepared by ultrasonic methods (ultrasonic homogenizer) in refrigerated storage of farmed sea bass was investigated. They studied effects of NEs from sunflower, canola, corn, olive, soybean, and hazelnut oils) on chemical, sensory, and microbial quality (mesophilic aerobic bacteria, total psychrophilic bacteria, and Enterobacteriaceae bacteria) of mentioned samples. They demonstrated that usage of those EOs-based NEs (regardless of oil type) could improve organoleptic parameters, reduce bacterial load, and extend shelf life of fresh fish. They reported that sensory scores of raw fillets increased with storage time, as well. However, in their study, olive and canola oils-based NEs showed more significant improvement in microbiological, and chemical assessments [177]. They suggested that industrial usage of NEs due to destabilizing the microorganism's lipid envelope, and with no need to use traditional chemical preservatives is of advantage to be considered for improvement of food storage.

Another study investigated stability effects of wheat germ oil-based NEs on cooked fish (mackerel) fillets stored at $4{ }^{\circ} \mathrm{C}$, which were prepared by ultrasonic approaches (114.7 $\mathrm{nm}$ average zeta size, $0.144 \mathrm{PD}$ index, $14.76 \mathrm{mV}$ zeta potential value). In addition to stability and preservative effects of wheat germ oil-based NEs, lipid nutritional quality indexes, color measurements, and the changes in sensory quality were assessed. It was reported that there is a stability in oil of the fish fillets, and delay in rapid oxidation, due to acceptable performance of wheat germ oil-based NEs [168]. According to the results acquired from this study, they demonstrated that incorporation of wheat germ oil-based NEs into fish fillets before cooking processes, can effectively preserve oils of the fish.

There is an ancient interest in citral-based EOs (as a flowering tree in Rutaceae) which is seen in a lot of citrus fruit. In an experimental study, authors aimed at formulation, and investigation of anti-microbial effects of citral based NEs prepared by ultrasonic-based approaches against some plant pathogens (Erwinia carotovora). Chosen NEs were made of citral (as the oil phase), chitosan (as a biopolymer carrier), tween 80 (as a surfactant), and sodium tripolyphosphate (TPP) (as a polyanion cross-linker), reached a physical stability (under circumstances of centrifugation at $5000 \mathrm{rpm}$ for $30 \mathrm{~min}$, and different storage temperature without phase separation), and viscosity. They reported enhanced anti-bacterial activity of citral-based NEs against Erwinia carotovora [178]. Interestingly, they reported the highest anti-bacterial activity of aforesaid EOs-based NEs was attributed to the lowest concentration, and the lowest size of citral-based NEs, due to the easiest and the most efficient incorporation of citral-based NEs into the bacterial cells.

Interestingly, there are some newly-invited patents, indicating important roles of EOs-based NEs fabricated by ultrasonic methods used in FP purposes. Two of the most well-known patents are based on the usage of saffron (comprising steps of: triturating stigmas of saffron in liquid nitrogen to obtain crushed saffron). In this patent, ultrasonic method resulted in the highest concentration of effective agent in saffron, with limited practical applications in comparison with the other methods [179,180].

In addition to mentioned EOs-based NEs, targeted delivery of EOs-based NEs has gained focus of attention among food scientist, food agriculturalists, aviculture technologists, and food biotechnologists in FP, in order to enrich the food ingredients, and indirectly lower pathogenesis of some food-borne pathogens. In a study, researchers aimed to conduct targeted delivery of one specialized and stabilized type of NEs through usage of flaxseed oil-based NEs prepared by ultrasonication, in order to investigate controlled and targeted release of those EOs-based NEs in simulated gastrointestinal fluids of broiler chicken. Results of this study reported enhancement, and up-regulation in the growth 
performance, lipid profile (long chain fatty acid desaturases and elongases), and oxidative stability, leading to omega-3 enrichment in broiler chickens [167].

\section{Conclusions}

As has been extensively described, there is a great concern for loss of food, especially in storage, and food processing, due to expired shelf life and loss of quality. Additionally, along with a substantial progress on food technology, there is a growingly demand for qualitatively-processed and ready-to-eat fresh food, necessitating FP, and keeping all quality parameters in food like: taste, moisture of storage, color, texture, and other processing features. According to the environmental drawbacks related to the conventional FP, and adverse side effects related to chemoactive FP, it seems that industrial usage of natural compounds with no synthetic additives like EOs-bases bioactive FP can be considered as the most efficient approach. EOs are extracted from aromatic herbal compounds, with proved anti-bacterial activities, indicating potentials for being used as food additives, and preservatives. By emergence of nanotechnology based approaches, it has been demonstrated that incorporation of EOs-based NEs can sufficiently increase food compatibility, develop easy dispersion of EOs in growing regions of microorganisms, and give a long-lasting stability against gravitational forces, creaming, and sedimentation in EOs. As there is possibility for loss of nutrients in food processing by thermal based approaches, ultrasonic technology has been emerged as a promising approach with potentiated ability for microbial protection, and keeping nutritional value of the food. In case of ultrasonic approaches, it is of high prominence to set up amplitude, nominal power, temperature, time, acoustic vibration, inert material used in probes, and frequency, for reaching to the most efficient and highly translucent EOs-based NEs in FP, refraining from food spoilage, and extending shelf life. Bactericidal effects and enzymatic inactivation of EOs-based NEs prepared by ultrasonic methods, are commonly subjected into cavitation effects, disrupting structural cell wall, and inducing cell lysis. For improved quality assurance purposes in FP and food safety, it can be proposed to use a combinative application of ultrasonic methods as high intensity approaches, and low intensity methods like thermal based ones.

Author Contributions: Both of the authors and co-authors who were listed on the title page, greatly helped to accomplishment of this study with unsparing efforts. M.N., helped to preparation of the last version of manuscript, investigation, and literature review. She also contributed to data curation, visualization, writing original draft, designation of images and tables, and final arrangement of the data making structure of the study. H.A., mainly did project supervision and corresponding, and verified the manuscript by the definitive approval for submission. He also academically and grammatically did peer revision, designation of methodological strategies and major conceptualization qualifying. H.A., also did scientific consultations, critical revision of the manuscript for important intellectual content according to the journal's instruction, and designation of methodological strategies. Both authors have read and agreed to the published version of the manuscript, and they have received an electronic copy of the manuscript. Additionally, they attest to the validity and legitimacy of data, and agreed to submit this manuscript to this journal.

Funding: All of the project was done by personal finance and this research gained no grant from funding agencies in the public, commercial, or not-for-profit sectors.

Institutional Review Board Statement: Not applicable.

Informed Consent Statement: Not applicable.

Data Availability Statement: Data is contained within the article.

Acknowledgments: All of the project was done by personal finance and this research gained no grant from any financial or not-for-profit sectors. All of the authors and co-authors who meet the criteria for authorship (according to the journal's instruction), are mentioned in the title page.

Conflicts of Interest: All of the authors and co-authors declare that there is no conflict of interest regarding to the concept and publication of this article. There are not any non-financial and other competing interest's disclosures. 


\section{References}

1. Al-Tayyar, N.A.; Youssef, A.M.; Al-Hindi, R. Antimicrobial food packaging based on sustainable Bio-based materials for reducing foodborne Pathogens: A review. Food Chem. 2020, 310, 125915. [CrossRef] [PubMed]

2. Altaf, U.; Kanojia, V.; Rouf, A. Novel packaging technology for food industry. J. Pharmacogn. Phytochem. 2018, 7, $1618-1625$.

3. Motelica, L.; Ficai, D.; Ficai, A.; Oprea, O.C.; Kaya, D.A.; Andronescu, E. Biodegradable Antimicrobial Food Packaging: Trends and Perspectives. Foods 2020, 9, 1438. [CrossRef] [PubMed]

4. Hao, R.; Roy, K.; Pan, J.; Shah, B.R.; Mraz, J. Critical review on the use of essential oils against spoilage in chilled stored fish: A quantitative me-ta-analyses. Trends Food Sci. Technol. 2021. [CrossRef]

5. Sharma, S.; Barkauskaite, S.; Jaiswal, A.K.; Jaiswal, S. Essential oils as additives in active food packaging. Food Chem. 2021, 343, 128403. [CrossRef] [PubMed]

6. Sharma, R.; Jafari, S.M.; Sharma, S. Antimicrobial bio-nanocomposites and their potential applications in food packaging. Food Control 2020, 112, 107086. [CrossRef]

7. Esmaili, F.; Sanei-Dehkordi, A.; Amoozegar, F.; Osanloo, M. A Review on the Use of Essential Oil-Based Nanoformulations in Control of Mosquitoes. Biointerface Res. Appl. Chem. 2021, 11, 12516-12529.

8. Yazgan, H.; Ozogul, Y.; Durmuş, M.; Balikçi, E.; Gökdoğan, S.; Uçar, Y.; Aksun, E.T. Effects of oil-in-water nanoemulsion based on sunflower oil on the quality of farmed sea bass and gilthead sea bream stored at chilled temperature ( $2 \pm 2$ C). J. Aquat. Food Prod. Technol. 2017, 26, 979-992. [CrossRef]

9. Saifullah, M.; Ahsan, A.; Shishir, M.R.I. Production, Stability and Application of Micro-and Nanoemulsion in Food Production and the Food Processing Industry, in Emulsions; Elsevier: Amsterdam, The Netherlands, 2016; pp. 405-442.

10. Lotfi, S.; Ahari, H.; Sahraeyan, R. The effect of silver nanocomposite packaging based on melt mixing and sol-gel methods on shelf life extension of fresh chicken stored at $4{ }^{\circ}$ C. J. Food Saf. 2019, 39, e12625. [CrossRef]

11. Majid, I.; Nayik, G.A.; Dar, S.M.; Nanda, V. Novel food packaging technologies: Innovations and future prospective. J. Saudi Soc. Agric. Sci. 2018, 17, 454-462. [CrossRef]

12. Brandelli, A.; Brum, L.F.W.; dos Santos, J.H.Z. Nanobiotechnology Methods to Incorporate Bioactive Compounds in Food Packaging. In Sustainable Agriculture Reviews; Springer Science and Business Media LLC: Berlin/Heidelberg, Germany, 2016; pp. 27-58.

13. Dávila-Rodríguez, M.; López-Malo, A.; Palou, E.; Ramírez-Corona, N.; Jiménez-Munguía, M.T. Essential oils microemulsions prepared with high-frequency ultrasound: Physical properties and antimicrobial activity. J. Food Sci. Technol. 2020, 57, 4133-4142. [CrossRef]

14. Turan, D.; Gunes, G.; Kilic, A. Perspectives of Bio-nanocomposites for Food Packaging Applications. Bionanocomposites Packag. Appl. 2017, 1-32. [CrossRef]

15. Hassanzad Azar, H.; Ghafari, A.; Yousefizadeh, S.; Fathollahi, M.; Aminzare, M. Antimicrobial Effects of the Nanoemulsion of Rosemary Essential Oil against Important Foodborne Pathogens. J. Hum. Environ. Health Promot. 2019, 5, 79-85.

16. Ribeiro-Santos, R.; Andrade, M.; Sanches-Silva, A. Application of encapsulated essential oils as antimicrobial agents in food packaging. Curr. Opin. Food Sci. 2017, 14, 78-84. [CrossRef]

17. Prakash, A.; Baskaran, R.; Paramasivam, N.; Vadivel, V. Essential oil based nanoemulsions to improve the microbial quality of minimally processed fruits and vegetables: A review. Food Res. Int. 2018, 111, 509-523. [CrossRef] [PubMed]

18. Hosseini, R.; Ahari, H.; Mahasti, P.; Paidari, S. Measuring the migration of silver from silver nanocomposite polyethylene packaging based on ( $\mathrm{TiO} 2)$ into Penaeus semisulcatus using titration comparison with migration methods. Fish. Sci. 2017, 83, 649-659. [CrossRef]

19. Ahari, H.; Lahijani, L. Migration of Silver and Copper Nanoparticles from Food Coating. Coatings 2021, 11, 380. [CrossRef]

20. Emamhadi, M.A.; Sarafraz, M.; Akbari, M.; Thai, V.N.; Fakhri, Y.; Linh, N.T.T.; Khaneghah, A.M. Nanomaterials for food packaging applications: A systematic review. Food Chem. Toxicol. 2020, 146, 111825. [CrossRef]

21. Enayatifard, R.; Akbari, J.; Babaei, A.; Rostamkalaei, S.S.; Hashemi, S.M.H.; Habibi, E. Anti-Microbial Potential of Nano-Emulsion form of Essential Oil Obtained from Aerial Parts of Origanum Vulgare, L. as Food Additive. Adv. Pharm. Bull. $2020,11,327$.

22. Ozogul, Y.; Boğa, E.K.; Akyol, I.; Durmus, M.; Uçar, Y.; Regenstein, J.M.; Kosker, A.R. Antimicrobial activity of thyme essential oil nanoemulsions on spoilage bacteria of fish and food-borne pathogens. Food Biosci. 2020, 36, 100635. [CrossRef]

23. Patra, J.K.; Baek, K.-H. Anti-Listerial Activity of Four Seaweed Essential Oils Against Listeria monocytogenes. Jundishapur J. Microbiol. 2016, 9, e31784. [CrossRef]

24. Santos, M.I.; Martins, S.R.; Veríssimo, C.S.C.; Nunes, M.J.C.; Lima, A.I.G.; Ferreira, R.B.; Pedroso, L.; Sousa, I.; Ferreira, M.A.S.S. Essential oils as antibacterial agents against food-borne pathogens: Are they really as useful as they are claimed to be? J. Food Sci. Technol. 2017, 54, 4344-4352. [CrossRef]

25. Shadman, S.; Hosseini, S.E.; Langroudi, H.E.; Shabani, S. Evaluation of the effect of a sunflower oil-based nanoemulsion with Zataria multiflora Boiss. essential oil on the physicochemical properties of rainbow trout (Oncorhynchus mykiss) fillets during cold storage. LWT 2017, 79, 511-517. [CrossRef]

26. Sahraneshin Samani, S.; Soleimanian-Zad, S.; Sheikh-Zeinoddin, M.; Fathi, M. Evaluation of Zataria multiflora Boiss. and Carum copticum L. Essential Oil Based Nanoemulsions in Inhibition of Byssochlamys fulva Growth in Apple Juice. J. Agric. Sci. Technol. 2019, 21, 357-368.

27. Salem, M.A.; Ezzat, M. Nanoemulsions in food industry. Some New Asp. Colloid. Syst. Foods 2019, 2, $238-267$. 
28. Schaefer, D.; Cheung, W. Smart Packaging: Opportunities and Challenges. Procedia CIRP 2018, 72, 1022-1027. [CrossRef]

29. Brockgreitens, J.; Abbas, A. Responsive Food Packaging: Recent Progress and Technological Prospects. Compr. Rev. Food Sci. Food Saf. 2015, 15, 3-15. [CrossRef]

30. Wyser, Y.; Adams, M.; Avella, M.; Carlander, D.; Garcia, L.; Pieper, G.; Rennen, M.; Schuermans, J.; Weiss, J. Outlook and Challenges of Nanotechnologies for Food Packaging. Packag. Technol. Sci. 2016, 29, 615-648. [CrossRef]

31. Rehman, A.; Jafari, S.M.; Aadil, R.M.; Assadpour, E.; Randhawa, M.A.; Mahmood, S. Development of active food packaging via incorporation of biopolymeric nanocarriers containing essential oils. Trends Food Sci. Technol. 2020, 101, 106-121. [CrossRef]

32. Nasiri, M.; Ahari, H.; Sharifan, A.; Anvar, A.A.; Kakolaki, S. Nanoemulsion production techniques upgrade bioactivity potential of nanoemulsified essential oils on Acipenser stellatus filet preserving. Int. J. Food Prop. 2020, 23, 2174-2188. [CrossRef]

33. Dávila-Rodríguez, M.; López-Malo, A.; Palou, E.; Ramírez-Corona, N.; Jiménez-Munguía, M.T. Antimicrobial activity of nanoemulsions of cinnamon, rosemary, and oregano essential oils on fresh celery. LWT 2019, 112, 108247. [CrossRef]

34. Bajpai, V.K.; Baek, K.-H.; Kang, S.C. Control of Salmonella in foods by using essential oils: A review. Food Res. Int. 2012, 45, 722-734. [CrossRef]

35. Dasgupta, N.; Ranjan, S.; Gandhi, M. Nanoemulsions in food: Market demand. Environ. Chem. Lett. 2019, 17, 1003-1009. [CrossRef]

36. Petkoska, A.T.; Daniloski, D.; D'Cunha, N.M.; Naumovski, N.; Broach, A.T. Edible packaging: Sustainable solutions and novel trends in food packaging. Food Res. Int. 2021, 140, 109981. [CrossRef]

37. Donsì, F.; Ferrari, G. Essential oil nanoemulsions as antimicrobial agents in food. J. Biotechnol. 2016, 233, 106-120. [CrossRef] [PubMed]

38. Jugreet, B.S.; Suroowan, S.; Rengasamy, R.K.; Mahomoodally, M.F. Chemistry, bioactivities, mode of action and industrial applications of essential oils. Trends Food Sci. Technol. 2020, 101, 89-105. [CrossRef]

39. Bhalla, Y.; Gupta, V.K.; Jaitak, V. Anticancer activity of essential oils: A review. J. Sci. Food Agric. 2013, 93, 3643-3653. [CrossRef] [PubMed]

40. Venkadesaperumal, G.; Rucha, S.; Sundar, K.; Shetty, P.H. Anti-quorum sensing activity of spice oil nanoemulsions against food borne pathogens. LWT 2016, 66, 225-231. [CrossRef]

41. Pavoni, L.; Perinelli, D.R.; Bonacucina, G.; Cespi, M.; Palmieri, G.F. An overview of micro-and nanoemulsions as vehicles for essential oils: Formulation, preparation and sta-bility. Nanomaterials 2020, 10, 135. [CrossRef] [PubMed]

42. Chang, Y.; McLandsborough, L.; McClements, D.J. Physicochemical Properties and Antimicrobial Efficacy of Carvacrol Nanoemulsions Formed by Spontaneous Emulsification. J. Agric. Food Chem. 2013, 61, 8906-8913. [CrossRef] [PubMed]

43. Ghosh, V.; Mukherjee, A.; Chandrasekaran, N. Eugenol-loaded antimicrobial nanoemulsion preserves fruit juice against, microbial spoilage. Colloids Surf. B 2014, 114, 392-397. [CrossRef] [PubMed]

44. Pinheiro, A.; Coimbra, M.; Vicente, A. In vitro behaviour of curcumin nanoemulsions stabilized by biopolymer emulsifiers-Effect of interfacial composition. Food Hydrocoll. 2015, 52, 460-467. [CrossRef]

45. Hilbig, J.; Ma, Q.; Davidson, P.M.; Weiss, J.; Zhong, Q. Physical and antimicrobial properties of cinnamon bark oil conanoemulsified by lauric arginate and Tween 80. Int. J. Food Microbiol. 2016, 233, 52-59. [CrossRef]

46. Moraes-Lovison, M.; Marostegan, L.F.; Peres, M.S.; Menezes, I.F.; Ghiraldi, M.; Rodrigues, R.A.; Fernandes, A.; Pinho, S.C. Nanoemulsions encapsulating oregano essential oil: Production, stability, antibacterial activity and incorporation in chicken pâté. LWT 2017, 77, 233-240. [CrossRef]

47. Noori, S.; Zeynali, F.; Almasi, H. Antimicrobial and antioxidant efficiency of nanoemulsion-based edible coating containing ginger (Zingiber officinale) essential oil and its effect on safety and quality attributes of chicken breast fillets. Food Control 2018, 84, 312-320. [CrossRef]

48. Abdou, E.S.; Galhoum, G.F.; Mohamed, E.N. Curcumin loaded nanoemulsions/pectin coatings for refrigerated chicken fillets. Food Hydrocoll. 2018, 83, 445-453. [CrossRef]

49. Prakash, A.; Vadivel, V.; Rubini, D.; Nithyanand, P. Antibacterial and antibiofilm activities of linalool nanoemulsions against Salmonella Typhimurium. Food Biosci. 2019, 28, 57-65. [CrossRef]

50. Ed-Dra, A.; Nalbone, L.; Filali, F.R.; Trabelsi, N.; El Majdoub, Y.O.; Bouchrif, B.; Giarratana, F.; Giuffrida, A. Comprehensive Evaluation on the Use of Thymus vulgaris Essential Oil as Natural Additive against Different Serotypes of Salmonella enterica. Sustainability 2021, 13, 4594. [CrossRef]

51. Chaudhari, A.K.; Singh, V.K.; Das, S.; Prasad, J.; Dwivedy, A.K.; Dubey, N.K. Improvement of in vitro and in situ antifungal AFB1 inhibitory and antioxidant activity of Origanum majorana L. essential oil through nanoemulsion and recommending as novel food preservative. Food Chem. Toxicol. 2020, 143, 111536. [CrossRef]

52. Chu, Y.; Gao, C.; Liu, X.; Zhang, N.; Xu, T.; Feng, X.; Yang, Y.; Shen, X.; Tang, X. Improvement of storage quality of strawberries by pullulan coatings incorporated with cinnamon essential oil nanoemulsion. LWT 2020, 122, 109054. [CrossRef]

53. Khoshbouy Lahidjani, L.; Ahari, H.; Sharifan, A. Influence of curcumin-loaded nanoemulsion fabricated through emul-sion phase inversion on the shelf life of Oncorhynchus mykiss stored at $4{ }^{\circ} \mathrm{C}$. J. Food Process. Preserv. 2020, 44, e14592. [CrossRef]

54. Xiong, Y.; Li, S.; Warner, R.D.; Fang, Z. Effect of oregano essential oil and resveratrol nanoemulsion loaded pectin edible coating on the preserva-tion of pork loin in modified atmosphere packaging. Food Control 2020, 114, 107226. [CrossRef]

55. Chu, Y.; Tang, X. Fabrication, structure and properties of pullulan-based active films incorporated with ultra-sound-assisted cinnamon essential oil nanoemulsions. Food Packag. Shelf Life 2020, 25, 100547. [CrossRef] 
56. Liew, S.N.; Utra, U.; Alias, A.K.; Tan, T.B.; Tan, C.P.; Yussof, N.S. Physical, morphological and antibacterial properties of lime essential oil nanoemulsions prepared via spontaneous emulsification method. LWT 2020, 128, 109388. [CrossRef]

57. Garzoli, S.; Petralito, S.; Ovidi, E.; Turchetti, G.; Masci, V.L.; Tiezzi, A.; Trilli, J.; Cesa, S.; Casadei, M.A.; Giacomello, P.; et al Lavandula $\mathrm{x}$ intermedia essential oil and hydrolate: Evaluation of chemical composition and antibacterial activity before and after formulation in nanoemulsion. Ind. Crop. Prod. 2020, 145, 112068. [CrossRef]

58. Shokri, S.; Parastouei, K.; Taghdir, M.; Abbaszadeh, S. Application an edible active coating based on chitosan- Ferulago angulata essential oil nanoemulsion to shelf life extension of Rainbow trout fillets stored at $4{ }^{\circ} \mathrm{C}$. Int. J. Biol. Macromol. 2020, 153, 846-854. [CrossRef] [PubMed]

59. Saada, N.S.; Abdel-Maksoud, G.; El-Aziz, M.A.; Youssef, A. Evaluation and utilization of lemongrass oil nanoemulsion for disinfection of documentary heritage based on parchment. Biocatal. Agric. Biotechnol. 2020, 29, 101839. [CrossRef]

60. Yazgan, H. Investigation of antimicrobial properties of sage essential oil and its nanoemulsion as antimicrobial agent. LWT 2020, 130, 109669. [CrossRef]

61. Prakash, A.; Baskaran, R.; Vadivel, V. Citral nanoemulsion incorporated edible coating to extend the shelf life of fresh cut pineapples. LWT 2020, 118, 108851. [CrossRef]

62. Liu, Q.; Gao, Y.; Fu, X.; Chen, W.; Yang, J.; Chen, Z.; Wang, Z.; Zhuansun, X.; Feng, J.; Chen, Y. Preparation of peppermint oil nanoemulsions: Investigation of stability, antibacterial mechanism and apoptosis effects. Colloids Surf. B 2021, $201,111626$. [CrossRef]

63. Cecchini, M.; Paoloni, C.; Campra, N.; Picco, N.; Grosso, M.; Perez, M.S.; Alustiza, F.; Cariddi, N.; Bellingeri, R. Nanoemulsion of Minthostachys verticillata essential oil. In-vitro evaluation of its antibacterial activity. Heliyon 2021, 7, e05896. [CrossRef]

64. Carpena, M.; Nuñez-Estevez, B.; Soria-Lopez, A.; Garcia-Oliveira, P.; Prieto, M.A. Essential Oils and Their Application on Active Packaging Systems: A Review. Resources 2021, 10, 7. [CrossRef]

65. Bouyahya, A.; Abrini, J.; Dakka, N.; Bakri, Y. Essential oils of Origanum compactum increase membrane permeability, disturb cell membrane integrity, and suppress quorum-sensing phenotype in bacteria. J. Pharm. Anal. 2019, 9, 301-311. [CrossRef]

66. Atarés, L.; Chiralt, A. Essential oils as additives in biodegradable films and coatings for active food packaging. Trends Food Sci. Technol. 2016, 48, 51-62. [CrossRef]

67. Fahmy, H.M.; Eldin, R.E.S.; Abu Serea, E.S.; Gomaa, N.M.; Aboelmagd, G.M.; Salem, S.A.; Elsayed, Z.A.; Edrees, A.; Shams-Eldin, E.; Shalan, A.E. Advances in nanotechnology and antibacterial properties of biodegradable food packaging materials. RSC Adv. 2020, 10, 20467-20484. [CrossRef]

68. Dhifi, W.; Bellili, S.; Jazi, S.; Bahloul, N.; Mnif, W. Essential Oils' Chemical Characterization and Investigation of Some Biological Activities: A Critical Review. Medicines 2016, 3, 25. [CrossRef] [PubMed]

69. Ahari, H.; Massoud, R. The Effect of Cuminum Essential Oil on Rheological Properties and Shelf Life of Probiotic Yoghurt. J. Nutr. Food Secur. 2020, 5, 296-305. [CrossRef]

70. Pandey, A.K.; Kumar, P.; Singh, P.; Tripathi, N.N.; Bajpai, V.K. Essential Oils: Sources of Antimicrobials and Food Preservatives Front. Microbiol. 2017, 7, 2161. [CrossRef] [PubMed]

71. McClements, D.; Öztürk, B. Utilization of Nanotechnology to Improve the Handling, Storage and Biocompatibility of Bioactive Lipids in Food Applications. Foods 2021, 10, 365. [CrossRef] [PubMed]

72. Pathania, R.; Khan, H.; Kaushik, R.; Khan, M.A. Essential Oil Nanoemulsions and their Antimicrobial and Food Applications Curr. Res. Nutr. Food Sci. J. 2018, 6, 626-643. [CrossRef]

73. Ferreira, C.D.; Nunes, I.L. Oil nanoencapsulation: Development, application, and incorporation into the food market. Nanoscale Res. Lett. 2019, 14, 1-13. [CrossRef]

74. Tripathi, A.D.; Sharma, R.; Agarwal, A.; Haleem, R. Nanoemulsions based edible coatings with potential food applications. Int. J. Biobased Plast. 2021, 3, 112-125. [CrossRef]

75. Zambrano-Zaragoza, M.L.; González-Reza, R.; Mendoza-Muñoz, N.; Miranda-Linares, V.; Bernal-Couoh, T.F.; Mendoza-Elvira, S.; Quintanar-Guerrero, D. Nanosystems in Edible Coatings: A Novel Strategy for Food Preservation. Int. J. Mol. Sci. 2018, 19, 705. [CrossRef]

76. Kalateh Seifari, F.; Ahari, H. Active edible films and coatings with enhanced properties using nanoemulsion and nanocrystals. Food Health 2020, 3, 15-22.

77. Souza, A.G.; Ferreira, R.R.; Paula, L.C.; Mitra, S.K.; Rosa, D.S. Starch-based films enriched with nanocellulose-stabilized Pickering emulsions containing different essential oils for possible applications in food packaging. Food Packag. Shelf Life 2021, $27,100615$. [CrossRef]

78. Díaz-Montes, E.; Castro-Muñoz, R. Edible Films and Coatings as Food-Quality Preservers: An Overview. Foods 2021, 10, 249. [CrossRef] [PubMed]

79. Hatziantoniou, S.; Deli, G.; Nikas, Y.; Demetzos, C.; Papaioannou, G. Scanning electron microscopy study on nanoemulsions and solid lipid nanoparticles containing high amounts of ceramides. Micron 2007, 38, 819-823. [CrossRef] [PubMed]

80. Salvia Trujillo, L. Nanoemulsions as Delivery Systems of Food Ingredients: Improving Food Safety and Functionality. Ph.D. Thesis, Universitat de Lleida, Lleida, Spain, 2014.

81. Li, W.; Chen, H.; He, Z.; Han, C.; Liu, S.; Li, Y. Influence of surfactant and oil composition on the stability and antibacterial activity of eugenol nanoemulsions. LWT-Food Sci. Technol. 2015, 62, 39-47. [CrossRef] 
82. Lahijani, L.K.; Ahari, H.; Sharifan, A. Enhancement of food safety using nanoemulsion with emphasize on fish food: A Review. Iran. J. Aquat. Anim. Health 2019, 5, 26-44. [CrossRef]

83. Fattahi, R.; Bahrami, A. Essential oils as a natural additive in the edible films and coatings (active packaging system): A Review. J. Babol Univ. Med. Sci. 2018, 20, 11-23.

84. Iamareerat, B.; Singh, M.; Sadiq, M.B.; Anal, A.K. Reinforced cassava starch based edible film incorporated with essential oil and sodium bentonite nanoclay as food packaging material. J. Food Sci. Technol. 2018, 55, 1953-1959. [CrossRef] [PubMed]

85. Chawla, R.; Sivakumar, S.; Kaur, H. Antimicrobial edible films in food packaging: Current scenario and recent nanotechnological advancements-a review. Carbohydr. Polym. Technol. Appl. 2021, 2, 100024.

86. Anis, A.; Pal, K.; Al-Zahrani, S.M. Essential Oil-Containing Polysaccharide-Based Edible Films and Coatings for Food Security Applications. Polymers 2021, 13, 575. [CrossRef]

87. Du, W.-X.; Avena-Bustillos, R.J.; Hua, S.S.T.; McHugh, T.H. Antimicrobial volatile essential oils in edible films for food safety. Sci. Against Microb. Pathog. 2011, 2, 1124-1134.

88. Artés-Hernández, F.; Martínez-Hernández, E.A.G.B.; Aguayo, E.; Gómez, P.A.; Artés, F. Fresh-Cut Fruit and Vegetables: Emerging Eco-friendly Techniques for Sanitation and Preserving Safety. Postharvest Handl. 2017, 7-45. [CrossRef]

89. Hasan, S.M.K.; Ferrentino, G.; Scampicchio, M. Nanoemulsion as advanced edible coatings to preserve the quality of fresh-cut fruits and vegetables: A review. Int. J. Food Sci. Technol. 2019, 55, 1-10. [CrossRef]

90. Azadbakht, E.; Maghsoudlou, Y.; Khomiri, M.; Kashiri, M. Development and structural characterization of chitosan films containing Eucalyptus globulus essential oil: Potential as an antimicrobial carrier for packaging of sliced sausage. Food Packag. Shelf Life 2018, 17, 65-72. [CrossRef]

91. Perdones, Á.; Escriche, I.; Chiralt, A.; Vargas, M. Effect of chitosan-lemon essential oil coatings on volatile profile of strawberries during storage. Food Chem. 2016, 197, 979-986. [CrossRef]

92. Pandey, A.K.; Chávez-González, M.L.; Silva, A.S.; Singh, P. Essential oils from the genus Thymus as antimicrobial food preservatives: Progress in their use as nanoemulsions-A new paradigm. Trends Food Sci. Technol. 2021, 111, 426-441. [CrossRef]

93. Chaudhari, A.K.; Singh, V.K.; Das, S.; Dubey, N.K. Nanoencapsulation of essential oils and their bioactive constituents: A novel strategy to control mycotoxin contamination in food system. Food Chem. Toxicol. 2021, 149, 112019. [CrossRef]

94. Bedoya-Serna, C.M.; Dacanal, G.C.; Fernandes, A.; Pinho, S.C. Antifungal activity of nanoemulsions encapsulating oregano (Origanum vulgare) essential oil: In vitro study and application in Minas Padrão cheese. Braz. J. Microbiol. 2018, 49, 929-935. [CrossRef]

95. Sharma, S.; Barkauskaite, S.; Duffy, B.; Jaiswal, A.K.; Jaiswal, S. Characterization and Antimicrobial Activity of Biodegradable Active Packaging Enriched with Clove and Thyme Essential Oil for Food Packaging Application. Foods 2020, 9, 1117. [CrossRef]

96. Azmi, N.A.N.; Elgharbawy, A.A.M.; Motlagh, S.R.; Samsudin, N.; Salleh, H.M. Nanoemulsions: Factory for Food, Pharmaceutical and Cosmetics. Processes 2019, 7, 617. [CrossRef]

97. Pradhan, N.; Singh, S.; Ojha, N.; Shrivastava, A.; Barla, A.; Rai, V.; Bose, S. Facets of Nanotechnology as Seen in Food Processing, Packaging, and Preservation Industry. BioMed Res. Int. 2015, 2015, 1-17. [CrossRef]

98. Dasgupta, N.; Ranjan, S. An Introduction to Food Grade Nanoemulsions; Springer Science and Business Media LLC.: Berlin/Heidelberg, Germany, 2018; Volume 13.

99. Walker, R.; Decker, E.A.; McClements, D.J. Development of food-grade nanoemulsions and emulsions for delivery of omega-3 fatty acids: Opportunities and obstacles in the food industry. Food Funct. 2014, 6, 41-54. [CrossRef] [PubMed]

100. Yalçınöz, Ş.; Erçelebi, E. Potential applications of nano-emulsions in the food systems: An update. Mater. Res. Express 2018, 5, 062001. [CrossRef]

101. Mei, L.; Wang, Q. Advances in Using Nanotechnology Structuring Approaches for Improving Food Packaging. Annu. Rev. Food Sci. Technol. 2020, 11, 339-364. [CrossRef] [PubMed]

102. Zambrano-Zaragoza, M.L.; Quintanar-Guerrero, D.; Mendoza-Muñoz, N.; Leyva-Gómez, G. Nanoemulsions and nanosized ingredients for food formulations. In Handbook of Food Nanotechnology; Elsevier: Amsterdam, The Netherlands, 2020.

103. Espitia, P.J.P.; Fuenmayor, C.A.; Otoni, C.G. Nanoemulsions: Synthesis, Characterization, and Application in Bio-Based Active Food Packaging. Compr. Rev. Food Sci. Food Saf. 2018, 18, 264-285. [CrossRef] [PubMed]

104. Aswathanarayan, J.B.; Vittal, R.R. Nanoemulsions and Their Potential Applications in Food Industry. Front. Sustain. Food Syst. 2019, 3, 95. [CrossRef]

105. Liu, Q.; Huang, H.; Chen, H.; Lin, J.; Wang, Q. Food-Grade Nanoemulsions: Preparation, Stability and Application in Encapsulation of Bioactive Compounds. Molecules 2019, 24, 4242. [CrossRef] [PubMed]

106. Tabibiazar, M.; Hamishehkar, H. Formulation of a Food Grade Water-In-Oil Nanoemulsion: Factors Affecting on Stability. Pharm. Sci. 2015, 21, 220-224. [CrossRef]

107. Silva, H.D.; Cerqueira, M.Â.; Vicente, A.A. Nanoemulsions for Food Applications: Development and Characterization. Food Bioprocess Technol. 2012, 5, 854-867. [CrossRef]

108. McClements, D.J.; Rao, J. Food-Grade Nanoemulsions: Formulation, Fabrication, Properties, Performance, Biological Fate, and Potential Toxicity. Crit. Rev. Food Sci. Nutr. 2011, 51, 285-330. [CrossRef]

109. Mehmood, T.; Ahmad, A.; Ahmed, A.; Ahmed, Z. Optimization of olive oil based O/W nanoemulsions prepared through ultrasonic homogenization: A response surface methodology approach. Food Chem. 2017, 229, 790-796. [CrossRef] [PubMed] 
110. Singh, N. An overview of the prospective application of nanoemulsions in foodstuffs and food packaging. ASIO J. Microbiol. Food Sci. Biotechnol. Innova. 2015, 1, 20-25.

111. Cardoso-Ugarte, G.A.; López-Malo, A.; Jiménez-Munguía, M.T. Application of nanoemulsion technology for encapsulation and release of lipophilic bioactive compounds in food. In Emulsions; Elsevier: Amsterdam, The Netherlands, 2016; pp. 227-255.

112. Mustafa, F.; Andreescu, S. Nanotechnology-based approaches for food sensing and packaging applications. RSC Adv. 2020, 10, 19309-19336. [CrossRef]

113. de Jesus Cenobio-Galindo, A.; Campos-Montiel, R.G.; Jiménez-Alvarado, R.; Almaraz-Buendía, I.; Medina-Pérez, G.; FernándezLuqueño, F. Development and incorporation of nanoemulsions in food. Int. J. Food Stud. 2019, 8. [CrossRef]

114. Bahrami, A.; Delshadi, R.; Assadpour, E.; Jafari, S.M.; Williams, L. Antimicrobial-loaded nanocarriers for food packaging applications. Adv. Colloid Interface Sci. 2020, 278, 102140. [CrossRef]

115. Bernardi, D.S.; Pereira, T.A.; Maciel, N.R.; Bortoloto, J.; Viera, G.S.; Oliveira, G.C.; Rocha-Filho, P.A. Formation and stability of oil-in-water nanoemulsions containing rice bran oil: In vitro and in vivo assessments. J. Nanobiotechnol. 2011, 9, 1-9. [CrossRef]

116. Ozogul, Y.; Yuvka, I.; Uçar, Y.; Durmus, M.; Kosker, A.R.; Öz, M.; Ozogul, F. Evaluation of effects of nanoemulsion based on herb essential oils (rosemary, laurel, thyme and sage) on sensory, chemical and microbiological quality of rainbow trout (Oncorhynchus mykiss) fillets during ice storage. LWT 2017, 75, 677-684. [CrossRef]

117. Farshbaf-Sadigh, A.; Jafarizadeh-Malmiri, H.; Anarjan, N.; Najian, Y. Preparation of Ginger Oil in Water Nanoemulsion Using Phase Inversion Composition Technique: Effects of Stirring and Water Addition Rates on their Physico-Chemical Properties and Stability. Z. Für Phys. Chem. 2019, 1. ahead-of-print. [CrossRef]

118. Nile, S.H.; Baskar, V.; Selvaraj, D.; Nile, A.; Xiao, J.; Kai, G. Nanotechnologies in Food Science: Applications, Recent Trends, and Future Perspectives. Nano-Micro Lett. 2020, 12, 1-34. [CrossRef]

119. Hosseinialhashemi, M.; Tavakoli, J.; Rafati, A.; Ahmadi, F. The aplication of Pistacia khinjuk extract nanoemulsion in a biopolymeric coating to improve the shelf life extension of sunflower oil. Food Sci. Nutr. 2021, 9, 920-928. [CrossRef]

120. Marchese, E.; D'Onofrio, N.; Balestrieri, M.L.; Castaldo, D.; Ferrari, G.; Donsì, F. Bergamot essential oil nanoemulsions: Antimicrobial and cytotoxic activity. Z. Für Nat. C 2020, 75, 279-290. [CrossRef]

121. Pinelli, J.J.; de Abreu Martins, H.H.; Guimarães, A.S.; Isidoro, S.R.; Gonçalves, M.C.; de Moraes, T.S.J. Essential oil nanoemulsions for the control of Clostridium sporogenes in cooked meat product: An alternative? LWT 2021, 143, 111123. [CrossRef]

122. Özogul, Y.; Özogul, F.; Kulawik, P. The antimicrobial effect of grapefruit peel essential oil and its nanoemulsion on fish spoilage bacteria and food-borne pathogens. LWT 2021, 136, 110362. [CrossRef]

123. Kumar, M.; Bishnoi, R.S.; Shukla, A.K.; Jain, C.P. Techniques for Formulation of Nanoemulsion Drug Delivery System: A Review. Prev. Nutr. Food Sci. 2019, 24, 225-234. [CrossRef] [PubMed]

124. Nasiri, M.; Sharifan, A.; Ahari, H.; Anvar, A.A.; Kakoolaki, S. Food-grade nanoemulsions and their fabrication methods to increase shelf life. Food Health 2019, 2, 26-31.

125. Klang, V.; Matsko, N.B.; Valenta, C.; Hofer, F. Electron microscopy of nanoemulsions: An essential tool for characterisation and stability assessment. Micron 2012, 43, 85-103. [CrossRef]

126. Ho, T.M.; Abik, F.; Mikkonen, K.S. An overview of nanoemulsion characterization via atomic force microscopy. Crit. Rev. Food Sci. Nutr. 2021, 1-21. [CrossRef]

127. Galvão, K.C.S.; Vicente, A.A.; Sobral, P.J.A. Development, Characterization, and Stability of O/W Pepper Nanoemulsions Produced by High-Pressure Homogenization. Food Bioprocess Technol. 2017, 11, 355-367. [CrossRef]

128. Keykhasalar, R.; Tabrizi, M.H.; Ardalan, P. Antioxidant Property and Bactericidal Activity of Linum usitatis-simum Seed Essential Oil Nanoemulsion (LSEO-NE) on Staphylococcus aureus. Int. J. Infect. 2020, 7, e101639. [CrossRef]

129. Ban, Z.; Zhang, J.; Li, L.; Luo, Z.; Wang, Y.; Yuan, Q.; Zhou, B.; Liu, H. Ginger essential oil-based microencapsulation as an efficient delivery system for the improvement of Jujube (Ziziphus jujuba Mill.) fruit quality. Food Chem. 2020, 306, 125628. [CrossRef] [PubMed]

130. Gallo, M.; Ferrara, L.; Naviglio, D. Application of Ultrasound in Food Science and Technology: A Perspective. Foods 2018, 7, 164. [CrossRef]

131. Abbas, S.; Hayat, K.; Karangwa, E.; Bashari, M.; Zhang, X. An Overview of Ultrasound-Assisted Food-Grade Nanoemulsions. Food Eng. Rev. 2013, 5, 139-157. [CrossRef]

132. Chen, F.; Zhang, M.; Yang, C.-H. Application of ultrasound technology in processing of ready-to-eat fresh food: A review. Ultrason. Sonochem. 2020, 63, 104953. [CrossRef] [PubMed]

133. Alarcon-Rojo, A.D.; Carrillo-Lopez, L.M.; Reyes-Villagrana, R.; Huerta-Jiménez, M.; Garcia-Galicia, I.A. Ultrasound and meat quality: A review. Ultrason. Sonochem. 2019, 55, 369-382. [CrossRef] [PubMed]

134. Chemat, F.; Khan, M.K. Applications of ultrasound in food technology: Processing, preservation and extraction. Ultrason. Sonochem. 2011, 18, 813-835. [CrossRef]

135. Majid, I.; Nayik, G.A.; Nanda, V. Ultrasonication and food technology: A review. Cogent Food Agric. 2015, 1, 1071022. [CrossRef]

136. Ashokkumar, M. Applications of ultrasound in food and bioprocessing. Ultrason. Sonochem. 2015, 25, 17-23. [CrossRef]

137. Awad, T.; Moharram, H.; Shaltout, O.; Asker, D.; Youssef, M. Applications of ultrasound in analysis, processing and quality control of food: A review. Food Res. Int. 2012, 48, 410-427. [CrossRef]

138. Taha, A.; Ahmed, E.; Ismaiel, A.; Ashokkumar, M.; Xu, X.; Pan, S.; Hu, H. Ultrasonic emulsification: An overview on the preparation of different emulsifiers-stabilized emulsions. Trends Food Sci. Technol. 2020, 105, 363-377. [CrossRef] 
139. Paniwnyk, L. Applications of ultrasound in processing of liquid foods: A review. Ultrason. Sonochem. 2017, 38, 794-806. [CrossRef]

140. Hardainiyan, S. A Review on Nanoemulsions in Food Applications. Insights Aquacult. Biotechnol. 2018, 2.

141. Ashokkumar, M. The characterization of acoustic cavitation bubbles-An overview. Ultrason. Sonochem. 2011, 18, 864-872. [CrossRef] [PubMed]

142. Yu, D.; Zhao, W.; Yang, F.; Jiang, Q.; Xu, Y.; Xia, W. A strategy of ultrasound-assisted processing to improve the performance of bio-based coating preservation for refrigerated carp fillets (Ctenopharyngodon idellus). Food Chem. 2021, 345, 128862. [CrossRef]

143. Bajerski, L.; Michels, L.R.; Colomé, L.M.; Bender, E.A.; Freddo, R.J.; Bruxel, F.; \& Haas, S.E. The use of Brazilian vegetable oils in nanoemulsions: An update on preparation and biological applica-tions. Braz. J. Pharm. Sci. 2016, 52, 347-363. [CrossRef]

144. Chandrapala, J.; Oliver, C.; Kentish, S.; Ashokkumar, M. Ultrasonics in food processing-Food quality assurance and food safety. Trends Food Sci. Technol. 2012, 26, 88-98. [CrossRef]

145. Vilkhu, K.; Manasseh, R.; Mawson, R.; AshokKumar, M. Ultrasonic Recovery and Modification of Food Ingredients; Springer Science and Business Media LLC.: Berlin/Heidelberg, Germany, 2010; pp. 345-368.

146. Teng, F.; He, M.; Xu, J.; Chen, F.; Wu, C.; Wang, Z.; Li, Y. Effect of ultrasonication on the stability and storage of a soy protein isolate-phosphatidylcholine nanoemul-sions. Sci. Rep. 2020, 10, 1-9.

147. Moradi, S.; Barati, A. Essential Oils Nanoemulsions: Preparation, Characterization and Study of Antibacterial Activity against Escherichia Coli. Int. J. Nanosci. Nanotechnol. 2019, 15, 199-210.

148. Aboutorab, M.; Ahari, H.; Allahyaribeik, S.; Yousefi, S.; Motalebi, A. Nano-emulsion of saffron essential oil by spontaneous emulsification and ultrasonic homogenization extend the shelf life of shrimp (Crocus sativus L.). J. Food Process. Preserv. 2021, 45, 15224. [CrossRef]

149. Najaf Najafi, M.; Nemati, S.; Mohammadi Sani, A.; Kadkhodaee, R. Evaluation of physical properties and stability of water-in-oilnanoemulsions containing saffron extract. Technol. Med. Aromatic Plants Iran 2020, 2, 12-24. [CrossRef]

150. Hamed Ahari, A.A.; Beik, S.A.; Moradi, S.; Rahimian, M. Formulation of Saffron and a Method of Preparation Thereof. U.S. Patent 17/086763, 23 March 2021.

151. Leong, T.S.H.; Manickam, S.; Martin, G.J.O.; Li, W.; Ashokkumar, M. Ultrasonic Production of Nano-Emulsions for Bioactive Delivery in Drug and Food Applications; Springer Science and Business Media LLC.: Berlin/Heidelberg, Germany, 2018.

152. Ahmadi, N.; Ahari, H. A Review of the Synthesis, Properties and Application of Nanoemulsions in the Packaging of Bioactive Foods. Sci. Q. J. Packag. Sci. Technol. Iran 2020, 11, 42-53.

153. Liu, Q.; Zhang, M.; Bhandari, B.; Xu, J.; Yang, C. Effects of nanoemulsion-based active coatings with composite mixture of star anise essential oil, polylysine, and nisin on the quality and shelf life of ready-to-eat Yao meat products. Food Control. 2020, 107, 106771. [CrossRef]

154. Meral, R.; Ceylan, Z.; Köse, Ş. Limitation of microbial spoilage of rainbow trout fillets using characterized thyme oil antibacterial nanoemulsions. J. Food Saf. 2019, 39, 12644. [CrossRef]

155. Rashed, M.M.A.; Tong, Q.; Nagi, A.; Li, J.; Khan, N.U.; Chen, L.; Rotail, A.; Bakry, A.M. Isolation of essential oil from Lavandula angustifolia by using ultrasonic-microwave assisted method preceded by enzymolysis treatment, and assessment of its biological activities. Ind. Crop. Prod. 2017, 100, 236-245. [CrossRef]

156. Salvia-Trujillo, L.; Rojas-Graü, A.; Soliva-Fortuny, R.; Martín-Belloso, O. Physicochemical Characterization of Lemongrass Essential Oil-Alginate Nanoemulsions: Effect of Ultrasound Processing Parameters. Food Bioprocess Technol. 2013, 6, 2439-2446. [CrossRef]

157. Zhang, S.; Zhang, M.; Fang, Z.; Liu, Y. Preparation and characterization of blended cloves/cinnamon essential oil nanoemulsions. LWT 2017, 75, 316-322. [CrossRef]

158. Ghosh, V.; Mukherjee, A.; Chandrasekaran, N. Ultrasonic emulsification of food-grade nanoemulsion formulation and evaluation of its bactericidal activity. Ultrason. Sonochem. 2013, 20, 338-344. [CrossRef]

159. Gul, O.; Saricaoglu, F.T.; Besir, A.; Atalar, I.; Yazici, F. Effect of ultrasound treatment on the properties of nano-emulsion films obtained from hazelnut meal protein and clove essential oil. Ultrason. Sonochem. 2018, 41, 466-474. [CrossRef]

160. Norcino, L.; Mendes, J.; Natarelli, C.; Manrich, A.; Oliveira, J.; Mattoso, L. Pectin films loaded with copaiba oil nanoemulsions for potential use as bio-based active packaging. Food Hydrocoll. 2020, 106, 105862. [CrossRef]

161. Roy, A.; Guha, P. Formulation and characterization of betel leaf (Piper betleL.) essential oil based nanoemulsion and its in vitro antibacterial efficacy against selected food pathogens. J. Food Process. Preserv. 2018, 42, e13617. [CrossRef]

162. Jo, Y.-J.; Chun, J.-Y.; Kwon, Y.-J.; Min, S.-G.; Hong, G.-P.; Choi, M.-J. Physical and antimicrobial properties of trans-cinnamaldehyde nanoemulsions in water melon juice. LWT 2015, 60, 444-451. [CrossRef]

163. Abbas, S.; Bashari, M.; Akhtar, W.; Li, W.W.; Zhang, X. Process optimization of ultrasound-assisted curcumin nanoemulsions stabilized by OSA-modified starch. Ultrason. Sonochem. 2014, 21, 1265-1274. [CrossRef]

164. Otoni, C.; Pontes, S.F.O.; Medeiros, E.A.A.; Soares, N.D.F.F. Edible Films from Methylcellulose and Nanoemulsions of Clove Bud (Syzygium aromaticum) and Oregano (Origanum vulgare) Essential Oils as Shelf Life Extenders for Sliced Bread. J. Agric. Food Chem. 2014, 62, 5214-5219. [CrossRef]

165. Raji, F.; Khanzadi, S.; Hashemi, M.; Azizzadeh, M. Effect of Chitosan Coating Nano-emulsion Containing Zataria multiflora and Bunium persicum Essential Oils on Escherichia Coli O157:H7 in Vacuum-packed Rainbow Trout Fillet. J. Hum. Environ. Health Promot. 2019, 5, 21-25. [CrossRef] 
166. Alizadeh, Z.; Yousefi, S.; Ahari, H. Optimization of bioactive preservative coatings of starch nanocrystal and ultrasonic extract of sour lemon peel on chicken fillets. Int. J. Food Microbiol. 2019, 300, 31-42. [CrossRef] [PubMed]

167. Jesser, E.; Lorenzetti, A.; Yeguerman, C.; Murray, A.; Domini, C.; Werdin-González, J. Ultrasound assisted formation of essential oil nanoemulsions: Emerging alternative for Culex pipiens pipiens Say (Diptera: Culicidae) and Plodia interpunctella Hübner (Lepidoptera: Pyralidae) management. Ultrason. Sonochem. 2020, 61, 104832. [CrossRef]

168. Abbasi, F.; Samadi, F.; Jafari, S.M.; Ramezanpour, S.; Shams-Shargh, M. Production of omega-3 fatty acid-enriched broiler chicken meat by the application of nanoencapsultsed flaxseed oil prepared via ultrasonication. J. Funct. Foods 2019, 57, 373-381. [CrossRef]

169. Ceylan, Z.; Meral, R.; Kose, Y.E.; Cavidoglu, I. Wheat germ oil nanoemulsion for oil stability of the cooked fish fillets stored at $4{ }^{\circ}$ C. J. Food Sci. Technol. 2019, 57, 1798-1806. [CrossRef] [PubMed]

170. Rao, J.; McClements, D.J. Formation of flavor oil microemulsions, nanoemulsions and emulsions: Influence of composition and preparation method. J. Agric. Food Chem. 2011, 59, 5026-5035. [CrossRef] [PubMed]

171. Sugumar, S.; Ghosh, V.; Nirmala, M.J.; Mukherjee, A.; Chandrasekaran, N. Ultrasonic emulsification of eucalyptus oil nanoemulsion: Antibacterial activity against Staphylococcus aureus and wound healing activity in Wistar rats. Ultrason. Sonochem. 2014, 21, 1044-1049. [CrossRef]

172. Gahruie, H.H.; Ziaee, E.; Eskandari, M.H.; Hosseini, S.M.H. Characterization of basil seed gum-based edible films incorporated with Zataria multiflora essential oil nanoemulsion. Carbohydr. Polym. 2017, 166, 93-103. [CrossRef]

173. Robledo, N.; Vera, P.; López, L.; Yazdani-Pedram, M.; Tapia, C.; Abugoch, L. Thymol nanoemulsions incorporated in quinoa protein/chitosan edible films; antifungal effect in cherry tomatoes. Food Chem. 2018, 246, 211-219. [CrossRef]

174. Ghazy, O.; Fouad, M.T.; Saleh, H.H.; Kholif, A.E.; Morsy, T.A. Ultrasound-assisted preparation of anise extract nanoemulsion and its bioactivity against different pathogenic bacteria. Food Chem. 2021, 341, 128259. [CrossRef]

175. He, Q.; Guo, M.; Jin, T.Z.; Arabi, S.A.; Liu, D. Ultrasound improves the decontamination effect of thyme essential oil nanoemulsions against Escherichia coli O157: H7 on cherry tomatoes. Int. J. Food Microbiol. 2021, 337, 108936. [CrossRef]

176. Fan, K.; Zhang, M.; Jiang, F. Ultrasound treatment to modified atmospheric packaged fresh-cut cucumber: Influence on microbial inhibition and storage quality. Ultrason. Sonochem. 2019, 54, 162-170. [CrossRef]

177. Khandpur, P.; Gogate, P.R. Evaluation of ultrasound based sterilization approaches in terms of shelf life and quality parameters of fruit and vegetable juices. Ultrason. Sonochem. 2016, 29, 337-353. [CrossRef]

178. Özogul, Y.; Durmus, M.; Uçar, Y.; Ozogul, F.; Regenstein, J.M. Comparative study of nanoemulsions based on commercial oils (sunflower, canola, corn, olive, soybean, and hazelnut oils): Effect on microbial, sensory, and chemical qualities of refrigerated farmed sea bass. Innov. Food Sci. Emerg. Technol. 2016, 33, 422-430. [CrossRef]

179. Marei, G.I.K.; Rabea, E.I.; Badawy, M.E.I. Ultrasonic Emulsification and Characterizations of Bio-based Nanoemulsion Formulations Containing Citral with Their Antimicrobial Activity. Egypt. Acad. J. Biol. Sci. F Toxicol. Pest Control 2017, 9, 169-182. [CrossRef]

180. Ahari, H.A.; AmirAli; Rahimian, M.; Allahyaribeik, S.; Moradi, S. Water-in-Oil Nano-emulsion of Saffron and A Method of Preparing Therof. U.S. Patent 17/174340, 3 June 2021. 